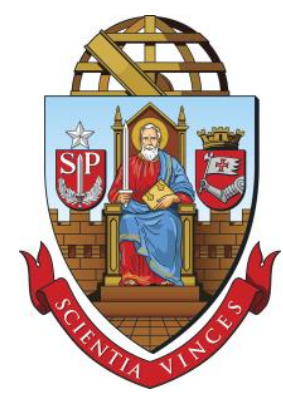

UNIVERSIDADE DE SÃO PAULO

FACULDADE DE MEDICINA DE RIBEIRAO PRETO

DEPARTAMENTO DE BIOQUIMICA E IMUNOLOGIA

Desenvolvimento de um modelo murino para estudo da resposta imune conferida pela proteína do Nucleocapsídeo do vírus Oropouche

PRISCILA ROSSE MAMANI ZAPANA

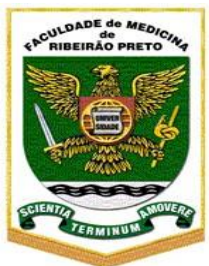

Ribeirão Preto-SP

2017 
PRISCILA ROSSE MAMANI ZAPANA

\title{
Desenvolvimento de um modelo murino para estudo da resposta imune conferida pela proteína do Nucleocapsídeo do vírus Oropouche
}

\begin{abstract}
Dissertação apresentada ao curso de Pósgraduação em Imunologia Básica e Aplicada do Departamento e Bioquímica e Imunologia da Faculdade de Medicina de Ribeirão Preto da Universidade de São Paulo, para obtenção do grau de Mestre em Ciências. Área de concentração: Imunologia Básica e Aplicada.
\end{abstract}

Orientador: Prof. Dr. Luiz Tadeu M. Figueiredo

Ribeirão Preto-SP

2017 
AUTORIZO A REPRODUÇÃO E DIVULGAÇÃO TOTAL OU PARCIAL DESTE TRABALHO, POR QUALQUER MEIO CONVENCIONAL OU ELETRÔNICO, PARA FINS DE ESTUDO E PESQUISA, DESDE QUE CITADA A FONTE.

FICHA CATALOGRÁFICA

Mamani-Zapana, Priscila R.

Desenvolvimento de um modelo murino para estudo da resposta imune conferida pela proteína do Nucleocapsídeo do vírus Oropouche. Ribeirão Preto, 2017.

Dissertação de Mestrado, apresentada à Faculdade de Medicina de Ribeirão Preto / USP. Área de concentração: Imunologia Básica e Aplicada.

Orientador: Luiz Tadeu M. Figueiredo.

1.Virus Oropouche

3. Resposta imune

2. Proteína do nucleocapsídeo

4. Modelo murino 
Nome: Mamani-Zapana, Priscila R.

Título: Desenvolvimento de um modelo murino para estudo da resposta imune conferida pela proteína do Nucleocapsídeo do vírus Oropouche.

Dissertação apresentada ao curso de Pós-Graduação em Imunologia Básica e Aplicada do Departamento de Bioquímica e Imunologia da Faculdade de Medicina de Ribeirão Preto da Universidade de São Paulo, para a obtenção do grau de Mestre em Ciências.

- Área de concentração: Imunologia Básica e Aplicada.

Aprovado em:

Banca Examinadora:

Prof. (a). Dr. (a). Instituição:

Julgamento: Assinatura:

Prof. (a). Dr. (a) Instituição:

Julgamento: Assinatura:

Prof. (a). Dr. (a). Instituição:

Julgamento: Assinatura: 
Trabalho realizado no Centro de Pesquisa em Virologia da Faculdade de Medicina de Ribeirão Preto - Universidade de São Paulo - USP, com o apoio financeiro da FAPESP e CAPES. 
"Dedicado a meus queridos pais Marcelina e Fortunato, e aos meus irmãos Braulio, Armando, Enrique, Guido, Harold, Belisario e Carolina” 


\section{AGRADECIMENTOS}

A Deus por ter me concedido a oportunidade de fazer meu mestrado neste maravilhoso pais, Brasil.

Ao Prof. Luiz Tadeu Moraes Figueiredo, por ter sido meu orientador durante este trabalho e pelo respeito e dedicação a mim neste tempo.

Agradeço ao Prof. Eurico Arruda e Jose Luiz Proença, foram essenciais para minha formação.

Agradeço aos seguintes amigos pesquisadores que colaboraram diretamente com o trabalho, através de auxilio em muitos dos experimentos envolvidos. Sem ajuda dessas pessoas este trabalho não teria sido possível: Alberto Anastacio Amarilla, Marcilio Jorge, Marcus Silva, Marjorie Cornejo, Anibal Oliveira.

Aos professores e alunos do Centro de Pesquisa em Virologia, pela constante troca de conhecimento e pelo convívio.

Agradeço à funcionaria Soraya Jabur Badra pelo suporte emocional que sempre me deu e a Maria Lucia pelo apoio nos experimentos e pelo carinho.

A meus colegas de Laboratório: Gilberto, Danilo, William, Leonardo, Lucia, Aline, Leonardo, Felipe, Marilia, Angelica.

A meus prezados amigos: Jenny Romero, Tatiana Veloso, Tiago Alves, Poliane Crisostomo, Juan Chuctaya, Felipe Canto, Carlismari, por serem meus irmãos neste tempo.

A meus amigos: Nayara Ruiz, Daysi Alves, Hudson Alves, por ter me acolhido sempre na sua casa como uma integrante dela e pelo carinho.

A todos os amigos e familiares pelo carinho e amor.

Muito obrigada. 
"A vida é nos concedida apenas como empréstimo; e a indagação de cada um devia ser: como poderei investir os meus talentos com o melhor proveito" como poderei fazer o máximo para a Gloria de Deus e o benefício de meus semelhantes? Pois a vida só tem valor se usada para a conquista desses objetivos"

Ellen G. White 
Priscila R. Mamani Z.

Desenvolvimento de um modelo murino para estudo da resposta imune conferida pela proteína do Nucleocapsídeo do vírus Oropouche.

Dissertação de Mestrado. Faculdade de Medicina de Ribeirão Preto, Universidade de São Paulo, Ribeirão Preto, SP, 2017.

Resumo

O vírus Oropouche (OROV) é um arbovírus que ocorre na região amazônica causando surtos de doenças febris agudas e que, ocasionalmente, podem ser associados a meningoencefalite. Aproximadamente 500.000 casos de Oropouche teriam ocorrido no Brasil. Entretanto, não existe vacina contra o OROV. O objetivo deste trabalho foi desenvolver um modelo animal de infecção por OROV para estudar a patogênese da doença e um modelo para testar candidatas vacinais. Protótipo vacinal utilizando a proteína recombinante do nucleocapsídeo (N) de OROV (NrOROV), que é o principal antígeno viral, foi usado como potencial candidato para vacina. Neste estudo utilizou-se um modelo animal em camundongos Balb/c de 12 semanas de idade, inoculados intracerebralmente com 8x10 5 PFU de OROV, capaz de induzir $100 \%$ de letalidade após o terceiro dia da infecção. Altos títulos virais foram encontrados no cérebro e na medula espinhal dos animais. Surpreendentemente, 12 e 24 horas pós-infecção foi possível detectar vírus no fígado e baço (3 Log10 PFU/g) dos camundongos. Com este modelo foram testados os candidatos vacinais. Grupos de camundongos foram imunizados 3 vezes com OROV, OROV e FCA, NrOROV, NrOROV e FCA, NrOROV, Poli I:C e Montanide ISA 720. Após 3 imunizações, os animais foram desafiados com 10 LD50 de OROV e observados por 20 dias. Os animais imunizados com NrOROV e adjuvantes, não foram capazes de produzir anticorpos neutralizantes e adquirir imunidade protetora contra OROV enquanto que os imunizados com OROV apresentaram altos níveis de anticorpos neutralizantes e completa proteção in vivo. Ainda, os anticorpos produzidos pelos animais imunizados permitiram estudar o ciclo de replicação celular do OROV utilizando imunofluorescência.

Palavras-chave: virus Oropouche, proteína do nucleocapsídeo, modelo murino, resposta imune. 
Priscila R. Mamani Z.

Development of a murine model to study the immune response conferred by Oropouche virus Nucleocapsid protein.

Masters dissertation. Faculty of Medicine of Ribeirão Preto, University of São Paulo, Ribeirão Preto, SP, 2017.

\section{Abstract}

Oropouche (OROV) is an arbovirus that occurs in the South American, Amazon region, producing outbreaks of acute febrile illness occasionally associated to meningoencephalitis. Approximately 500,000 cases of Oropouche have been reported in Brazil in the last 60 years. However, there is no available vaccine for OROV. We show here the development of an animal model of OROV suitable for studies on pathogenesis and vaccine testing. A vaccine prototype based on recombinant OROV nucleocapsid protein (NrOROV), an important viral antigen, was evaluated in the animal model. Initialy, we observed that all 12-week-old Balb/c mice inoculated intracerebrally with $8 \times 10^{5}$ PFU died after the third day of infection. Surprisingly, OROV genome was detectable in the liver as early as 12 hours post infection (pi) and in the spleen at 24 hours pi at $3 \log _{10} \mathrm{PFU} / \mathrm{g}$. Besides, high viral titers were found in brain and spinal cord. To test the NrOROV as a vaccine candidate, animals divided in 5 groups were immunized subcutaneously 3 times, two weeks apart with either OROV, OROV and Freud complete Adjuvant (FCA), NrOROV, NrOROV and FCA, NrOROV and Poly I:C and Montanide ISA 720. The experiment also included a group of naïve animals. After the third immunization, the animals were challenged with $10 \mathrm{LD}_{50}$ by intracerebral route and followed for 20 days. The animals immunized with NrOROV and adjuvants developed specific antibodies that were not able to neutralize the virus or confer protective immunity against OROV. Nevertheless, mice immunized with OROV showed high levels of neutralizing and protective antibodies. Despite the discouraging results with NrOROV as a vaccine, the mouse model is suitable to study pathogenesis, and to test other vaccines for OROV.

Key words: Oropouche virus, nucleocapsid protein, murine model, immune response. 


\section{SUMARIO}

1. INTRODUÇÃO.

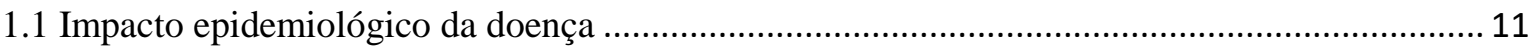

$1.2 \mathrm{O}$ ciclo viral e aspectos moleculares da patogênese ..................................................................... 14

1.3 Estratégias vacinais voltadas para o controle do OROV ........................................................ 19

1.4 Modelos experimentais para o estudo da febre de Oropouche ................................................. 19

1.5 Perspectivas e principais desafios para o desenvolvimento de una vacina eficaz contra a febre de Oropouche.

1.5 Perspectivas e principais desafios para o desenvolvimento de una vacina eficaz contra a febre de Oropouche.

2. OBJETIVOS

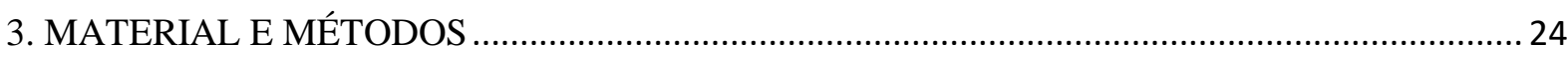

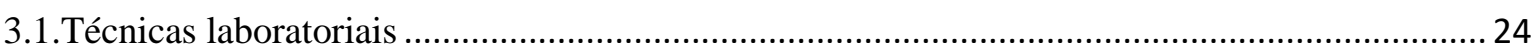

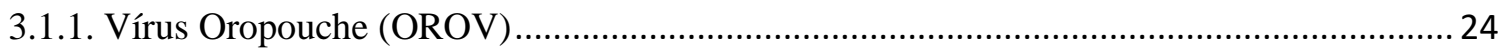

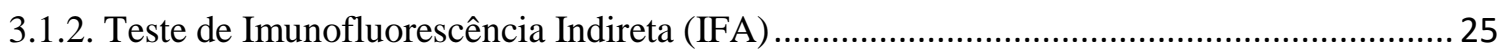

3.1.3. Reação em cadeia pela polimerase precedida de transcrição reversa (RT - PCR).............. 26

3.1.4. Seqüenciamento nucleotídico de amplicons pelo método de Sanger ................................. 27

3.1.5. Teste de plaques para quantificação dos estoques virais, fluidos e tecidos dos animais .... 28

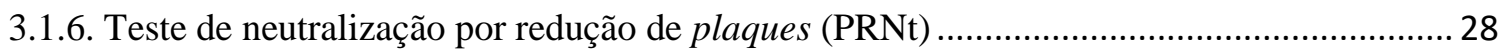

3.1.7. Ensaio imuno-enzimático para pesquisa de anticorpos contra OROV utilizando células

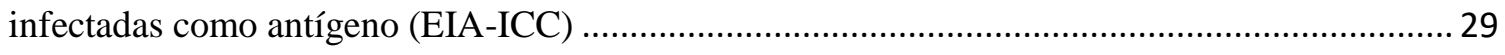

3.1.8. Dose letal para 50\% $\left(\mathrm{LD}_{50}\right)$ dos camundongos Balb/c adultos ......................................... 30

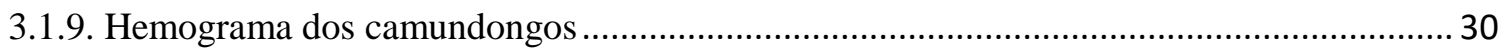

3.1.10. SDS-PAGE e Western Blot da proteína recombinante do Nucleocapsideo de OROV

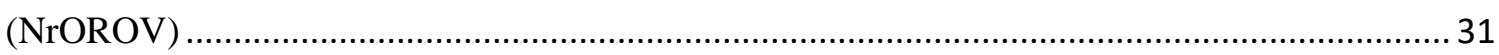

3.2. Modelo experimental de infecção por OROV em camundongos .............................................. 31

3.2.1. Coleta de órgãos e fluidos dos camundongos para quantificação de OROV ....................... 32

3.2.2. Inóculos antigênicos contendo NrOROV e controles do experimento ................................. 32 
3.2.3. Protocolo de imunização com NrOROV e desafio dos animais com OROV

3.2.4. Avaliação da proteção conferida por NrOROV com base na sobrevida, peso e score clínico

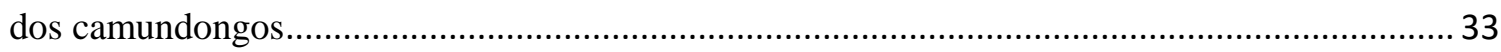

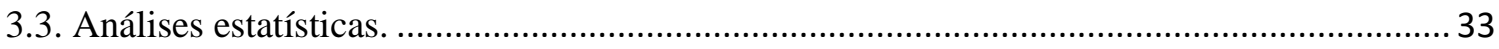

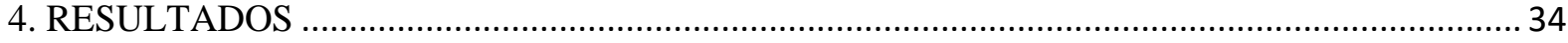

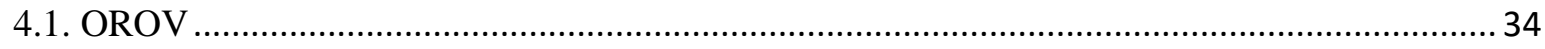

4.2. A proteína $\mathrm{N}$ recombinante do vírus Oropouche (NrOROV) ..................................................... 36

4.3. O modelo experimental de infecção por OROV em camundongos............................................ 36

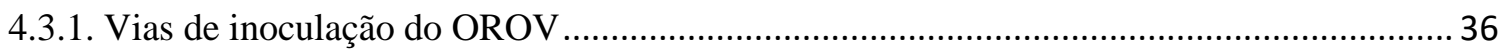

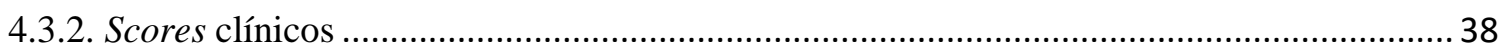

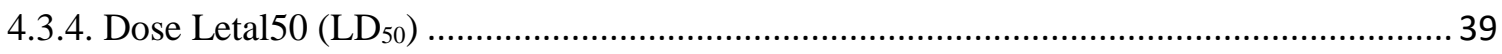

4.3.3. OROV nos órgãos de camundongos infectados via i.c................................................... 39

4.4. Aplicação do modelo murino no estudo da resposta imune conferida pela NrOROV ............... 41

4.4.1. Avaliação clínica e dos parâmetros hematológicos nos animais pós-imunizados ............... 41

4.4.2. Resposta humoral induzida pelas imunizações com antígeno NrOROV ............................. 42

4.4.3 Imunofluorescência Indireta (IFA) em microscópio confocal............................................. 44

4.4.4. Sobrevida, peso e score clínico dos animais imunizados com NrOROV, após desafio com

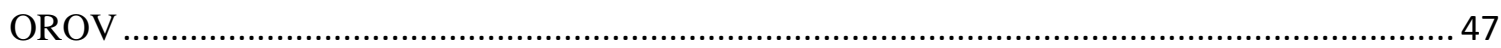

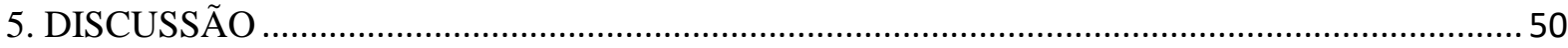

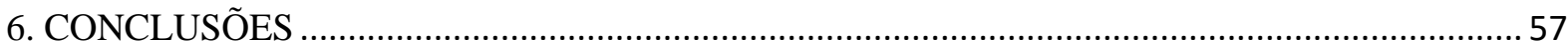

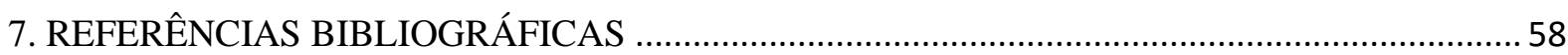




\section{LISTA DE FIGURAS}

Figura 1. Representação esquemática da organização genômica (a) e topologia (b) da glicoproteína cepa BeAn 19991 do vírus de Oropouche.

Figura 2. Esquema representando o ciclo de replicação do Orthobunyavirus.

Figura 3. IFA para OROV em células C6/36 observadas com aumento de 40x

Figura 4. RT-PCR do estoque de OROV em células C6/36.

Figura 5. Sequências nucleotídicas dos segmentos S e L de OROV.

Figura 6. Western blot de amostras contendo $\mathrm{N}=6 \mu \mathrm{g} / 12 \mu \mathrm{l}$ e $\mathrm{N}^{*}=12 \mu \mathrm{g} / 24 \mu \mathrm{l}$. De NrOROV mostrando reatividade com anticorpos murinos.

Figura 7. Porcentual de sobrevida de camundongos infectados com OROV por diferentes vias de inoculação.

Figura 8. Score clínicos de camundongos Balb/C de 3 e 6 semanas de idade inoculados pela via intracerebral com OROV. 38

Figura 9. Representação gráfica da sobrevivência de grupos de camundongos Balb/C de 12 semanas de idade, inoculados por via intracerebral

Figura 10. Carga de OROV em PFU/g de tecido, no cérebro, medula espinhal, fígado, baço, soro, rins, pulmão e coração dos camundongos infectados.

Figura 11. Protocolo de imunização com NrOROV e desafio dos 6 grupos de animais com OROV, incluindo controles positivo e negativo.

Figura 12.Títulos séricos de IgG contra OROV nos 6 grupos de camundongos utilizados nos experimentos de imunização

Figura 13. Títulos séricos de IgG contra NrOROV nos 6 grupos de camundongos utilizados nos experimentos de imunização.

Figura 14. Teores de anticorpos neutralizantes com base na redução de PFU. Dos soros dos 6 grupos de animais que participaram dos experimentos de imunização com NrOROV ...........44

Figura 15. Fotografias de imunofluorescencia utilizando células HeLa infectadas com OROV para pesquisa de anticorpos anti-OROV em soro de camundongos.

Figura 16. Cinetica da Proteina N de OROV.

Figura 17. Porcentual de sobrevivência e mortalidade de camundongos imunizados. 
Figura 18. Evolução dos pesos dos camundongos imunizados.

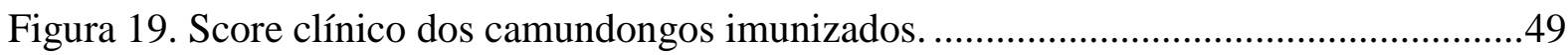




\section{LISTA DE TABELAS}

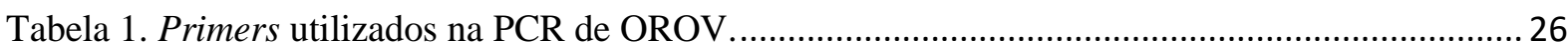

Tabela 2. Reagentes para mistura de reação da PCR para OROV ....................................................... 27

Tabela 3 - Grupos de animais submetidos aos experimentos de imunização com NrOROV ............... 33

Tabela 4 - Score clinico dos camundongos inoculados pela via i.c com OROV ................................. 38

Tabela 5 - Analises hematológico dos grupos de camundongos imunizados..................................... 42 


\section{ABREVIATURAS E SIGLAS}

$\mu$ l-Microlitro

$\mu$ M-Micro molar

cDNA- do inglês, complemetary DNA

DL50 - Dose letal 50

EDTA- do inglês, Ethylenediamine tetraacetic acid

ELISA- Teste imunoenzimatico

FCA- adjuvante completo de Freud, do inglês, Freud Complete Adjuvant

i.c.- intracerebral

i.p.-intrperitoneal

IgG- Imunoglobulina G

IgM- Imunoglobulina M

Mg-Miligrama

MIAF-Mouse imunoascitic fluid (fluido imunoascitico de camundongo)

NrOROV-Proteina recombinante de nucleocapsideo do vírus Oropouche.

OROV-Virus Oropouche

p.i.- pos infecção

pb-pares de bases

PBS-Tampão salina fosfato, do inglês, Phosphate Buffered Saline

RNA-Ácido ribonucleico, do inglês, Ribonucleic Acid

s.c.-subcutaneo

SBF-Soro bovino fetal

seg-segundos

v.c.- veia caudal 


\section{INTRODUÇÃO.}

\subsection{Impacto epidemiológico da doença}

O vírus Oropouche (OROV) é um dos arbovírus mais comuns que infectam seres humanos no Brasil. Estima-se que, desde o primeiro isolamento do vírus em 1955, tenha afetado mais de meio milhão de pessoas. No entanto, o número exato de casos é difícil de determinar, porque a infecção é subnotificada devido à semelhança de seus sintomas com os de outras doenças febrís arbovirais, como Dengue, Zika, Chikungunya e febre Mayaro. A falta de um diagnóstico exato em hospitais e centros de saúde dificulta a notificação epidemiológica adequada, razão pela qual o número estimado de casos é menor do que, provavelmente, está ocorrendo na população, especialmente na região endêmica da Amazônia (DA ROSA et al., 2017).

O OROV é o agente causador da febre de Oropouche, uma doença arboviral febril freqüentemente associada à região amazônica brasileira (PINHEIRO; TRAVASSOS DA ROSA; VASCONCELOS P, 1994). O primeiro caso de febre de Oropouche foi descrito em Trinidad e Tobago em 1955: o vírus (cepa TRVL 9760) foi isolado do sangue de um residente febril de uma aldeia chamada Vega de Oropouche, a 3 milhas ao norte de Sangre Grande (ANDERSON et al., 1961). Outra cepa de OROV foi isolada de um pool de 177 mosquitos de Coquillettidia venezuelensis coletados em Bush Bush Forest, Nariva Swamp, Trinidad, em 18 de Outubro de 1960. Esta segunda cepa (TRVL 35111) estava antigeneticamente relacionada com a cepa protótipo TRVL 9760 por testes de fixação de complemento (FC) e neutralização (TN) (ANDERSON et al., 1961). O vírus foi isolado pela primeira vez no Brasil, em 1960, do sangue de uma preguiça, Bradypus trydactilus, capturado em uma área florestal durante a construção da rodovia Belém-Brasília e também, de um grupo de mosquitos de Ochlerotatus serratus capturados perto da mesma área (PINHEIRO F et al., 2004).

No ano seguinte, o vírus foi novamente detectado na cidade de Belém, Estado do Pará. Nessa ocasião, uma grande epidemia de febre de Oropouche foi relatada com cerca de 11 mil pessoas afetadas (PINHEIRO et al., 1962). Com esse surto, OROV demonstrou seu 
potencial epidêmico e muitos outros surtos foram descritos em áreas urbanas dos estados do Acre, Amapá, Amazonas, Maranhão, Pará, Rondônia e Tocantins, bem como em outros países da América do Sul, como o Panamá, em 1989, e na região amazônica do Peru, entre 1992 e 1994. (CHAVEZ; COLAN; PHILLIPS, 1992; PINHEIRO; TRAVASSOS DA ROSA; VASCONCELOS P, 1994; WATTS et al., 1997a).

Mais recentemente, o OROV foi relatado nos municípios de Parauapebas, Porto de Moz, Igarapé Açu, Magalhães Barata e Maracanã, no Estado do Pará, na região Bragantina, região onde o vírus já havia sido detectado em 1970. (AZEVEDO et al., 2007; VASCONCELOS et al., 2009). Em 2009, surto de OROV foi relatado nos municípios de Altamira e Santa Bárbara, Estado do Pará, e posteriormente em Marzagão, estado do Amapá (VASCONCELOS et al., 2011).

Seres humanos podem ser infectados por OROV pela picada de mosquitos infectados, sendo de 4 a 8 dias o período de incubação. A doença tem início súbito, com febre que pode chegar a $40^{\circ} \mathrm{C}$, cefaléia, mialgia, artralgia, calafrios, fotofobia e prostração (PINHEIRO et al., 1982). Ocasionalmente, pode ocorrer exantema e infecção do sistema nervoso central. Não há relato de casos fatais por OROV (LEDUC; PINHEIRO F, 1989). A maioria dos sintomas desaparecem entre 3 a 5 dias, embora a mialgia possa durar 1 ou 2 semanas. Até 10 dias após o fim do quadro febril, cerca de $50 \%$ dos pacientes podem apresentar recorrência de alguns sintomas (VASCONCELOS et al., 1989). No entanto, a viremia é detectável, na maior parte dos pacientes, 2 a 3 dias após o início da doença. Também, é possível que ocorra infecção por OROV em aerossol, como observado em acidente laboratorial (PINHEIRO et al., 1981). A febre do Oropouche pode estar associada a abortamento até o segundo mês de gestação (PINHEIRO F; TRAVASSOS DA ROSA; VASCONCELOS, 1997). No entanto, seu diagnóstico clínico é difícil, pela inespecificidade da sintomatologia (SAEED et al., 2000).

Entre 1981 e 1996, foram registrados surtos de febre do Oropouche no estado do Pará (Oriximiná, mesorregião baixa Amazonas, Brasil Novo e Altamira, mesorregião sudeste); Como nos municípios de Manaus, Novo Airão e Barcelos (Estado do Amazonas), Mazagão (Estado do Amapá), Xapuri (Estado do Acre), Ariquemes, Machadinho e Ouro Preto d'Oeste (Estado de Rondônia), Porto Franco e Estreito (Maranhão) e Tocantinópolis (Tocantins). Em 2000 e 2010, o vírus foi, em 2 ocasiões, isolado de macacos silvestres 
(Callithrix penicillata) oriundos do Estado de Minas Gerais (NUNES et al., 2005; TILSTON-LUNEL et al., 2015a).

Em 2003 e 2004, foram detectados focos de febre do Oropouche nos municípios de Parauapebas e Porto de Moz (região média do baixo Amazonas) (AZEVEDO et al., 2007). Em 2006, foram registradas mais epidemias de OROV nos municípios de Maracanã, Igarapé-Açu, Magalhães Barata e Viseu localizados na região de Bragantina, nordeste do Pará, demonstrando o ressurgimento do vírus após 26 anos de silêncio epidemiológico na região (VASCONCELOS et al., 2009). Em 2009, OROV surgiu nos municípios de Santa Bárbara (região metropolitana de Belém), Altamira (mesorregião sudeste) e em Marzagão, estado do Amapá (VASCONCELOS et al., 2011).

Fora do Brasil, foram registradas epidemias no Panamá e no Peru. O surto no Panamá foi registrado em 1989 na Vila do Bejuco, localizada a cerca de $50 \mathrm{~km}$ a oeste da Cidade do Panamá, capital do país. No Peru, a febre ORO foi documentada em 1992, quando o vírus causou um surto na cidade de Iquitos (CHAVEZ; COLAN; PHILLIPS, 1992; WATTS et al., 1997b). Além disso, outros dois surtos de OROV foram registrados na Amazônia peruana em 1994, nas cidades de Puerto Maldonado e Madre de Dios (BAISLEY et al., 1998).

Em geral, as taxas de incidência estimadas para infecção por OROV foram determinadas por inquéritos seroepidemiológicos, incluindo famílias selecionadas aleatoriamente. Nesse caso, foi aplicado um levantamento clínico-epidemiológico aos membros de cada família e coletaram-se amostras de sangue para isolamento do vírus (fase aguda) em camundongos recém-nascidos (2-3 dias) e células Vero, bem como para a detecção de TN, FC, HI e anticorpos IgM (fase convalescente) (PINHEIRO F et al., 2004; VASCONCELOS et al., 1989).

Embora coeficientes de incidência não tenham sido determinados em alguns surtos, uma característica relevante da febre do Oropouche está relacionada a um grande número de infecções em todos os eventos epidêmicos descritos até agora. Com base em registros oficiais, os casos globais de febre do Oropouche foram estimados em 380000 casos durante o período de 1961 a 2007. É importante notar que em vários surtos a uniformidade na distribuição numérica dos casos, bem como na incidência estimada não mostrou-se homogênea. De fato, a taxa de incidência média foi estimada em 30\%. Em uma epidemia, a 
proporção de indivíduos infectados por OROV com sintomas clínicos atingiu 63\% (FREITAS et al., 1982).

As taxas de infecção por OROV são bastante variadas. Em 1979, durante o surto na região Bragantina do Pará, as mulheres foram o grupo mais infectado. Por outro lado, no mesmo ano, outro surto ocorreu na cidade de Belém, onde os homens foram os mais afetados (PINHEIRO et al., 1981a). Em um surto registrado em Santarém, Estado do Pará, a proporção de mulheres infectadas foi 2 vezes maior que na população masculina. Além disso, a febre do Oropouche afeta todos os grupos etários, embora em alguns surtos a incidência tenha sido maior em crianças e adultos jovens (PINHEIRO et al., 1976; PINHEIRO F et al., 2004).

\section{$1.2 \mathrm{O}$ ciclo viral e aspectos moleculares da patogênese}

Estudos realizados sugerem que OROV é mantido na natureza em dois ciclos distintos, um silvestre e outro urbano (PINHEIRO et al., 1982a). No ciclo silvestre, há evidências de que preguiças (Bradypus tridactylus), primatas não humanos e algumas aves selvagens sejam hospedeiros vertebrados (NUNES et al., 2005; PINHEIRO et al., 1981a; TILSTON-LUNEL et al., 2015a). O vetor de OROV na floresta não está claro. Em 2 ocasiões, o agente foi isolado de mosquitos silvestres, ambos em 1960. Um isolamento foi de O. serratus coletado na região amazônica do Brasil e o segundo foi de Coquilletidia venezuelensis em Trinidad (PINHEIRO et al., 1981a; PINHEIRO F et al., 2004).

No ciclo urbano ou epidêmico, os seres humanos aparentemente são os únicos vertebrados envolvidos, uma vez que estudos com animais domésticos (por exemplo, cães, gatos e galinhas) excluíram o papel desses animais na manutenção do ciclo urbano (PINHEIRO et al., 1981a). Os seres humanos são provavelmente também a ligação entre os ciclos selvático e urbano, quando os seres humanos invadem a floresta, tornam-se infectados, e retornam às áreas urbanas durante o período de viremia (PINHEIRO et al., 1981a). Dois vetores são encontrados geralmente em epidemias urbanas: o inseto antropofílico Culicoides paraensis (Ceratopogonidae), regionalmente nomeado como "maruim", e o mosquito Culex p. Quinquefasciatus (Culicidae). Em experimentos laboratoriais com o Culex $p$. Quinquefasciatus, o inseto provou ser um vetor ineficiente de 
OROV (HOCH et al., 1987). Além disso, Cardoso e outros detectaram a SRNA de OROV em pacientes e em Culex quinquefasciatus, reforçando a provável participação de mosquitos Culex no ciclo urbano de OROV (CARDOSO et al., 2015).

OROV é um membro da família Bunyaviridae, gênero Orthobunyavirus, sorogrupo Simbu, (ELLIOTT, 2014). Embora não tenham sido publicados estudos ultraestruturais específicos de OROV em tecidos humanos até à data, é provável que este agente viral exiba partículas com características morfológicas semelhantes a outros membros do género Orthobunyavirus. Estudos ultraestruturais do vírus La Crosse mostraram que as partículas do vírus são esféricas, medindo entre 80 e 110 nm de diâmetro, cercadas por um envelope lipídico (TALMON et al., 1987). Internamente, a partícula viral contém três segmentos negativos de sentido único de ARN genômico de diferentes tamanhos que são individualmente Ligadas à proteína $\mathrm{L}$ (ARN polimerase $\mathrm{ARN}$ viral dependente) e que estão rodeadas pela proteína nucleocápside $(\mathrm{N})$, formando três ribonucleoproteínas (MURPHY; HARRISON; WHITFIELD, 1973).

Os segmentos genômicos são denominados pequeno (S), médio (M) e grande (L), com base em seus respectivos tamanhos moleculares. $\mathrm{O}$ genoma viral parcial para o protótipo brasileiro OROV estirpe BeAn 19991 foi sequenciado e recentemente foram descritas sequências genômicas completas para os três segmentos, incluindo as regiões não codificantes completas (NCRs), mostrando um segmento S de 958 nucleótidos, um M com 4385 nucleótidos E um L com 6,852 nucleótidos (ACRANI et al., 2015; MORELI et al., 2002; TILSTON-LUNEL et al., 2015a).

As sequências codificadoras dos 3 segmentos genômicos são flanqueadas por duas NCRs terminais, nomeadamente $5^{\prime}$ e $3^{\prime}$ NCRs, que têm um número diferente de nucleótidos, mas incluem 11 nucleótidos que são altamente conservados entre os três segmentos de RNA (Figura 1). Estas regiões são complementares entre si numa disposição própria à circularização no RNA genômico, essencial para a atividade promotora de replicação e transcrição, como indicado recentemente num ensaio de sistema de minigenoma que introduziu mutações nos NCRs (TILSTON-LUNEL et al., 2015a).

O segmento L contém uma estrutura de leitura aberta (ORF) que codifica a proteína L, uma ARN polimerase dependente de ARN. A proteína L tem um peso molecular de 261,25 kDa e está associada aos três segmentos de ARN virais (AQUINO; FIGUEIREDO, 
2004). O segmento M contém uma única ORF que codifica uma grande poliproteína que é clivada após ou durante a tradução, produzindo três proteínas virais, duas glicoproteínas de superfície estrutural: Gn $(28,03 \mathrm{kDa})$ e Gc $(107,14 \mathrm{kDa})$ e uma proteína não estrutural denominada NSm (26,65 kDa) (DIETZGEN et al., 2012). O segmento S codifica uma proteína estrutural de nucleocápside $(26,26 \mathrm{kDa})$ e uma proteína NSs não estrutural $(10,65$ $\mathrm{kDa}$ ), em duas ORFs sobrepostas. Recentemente, o resgate de vírus OROV recombinantes por genética reversa sem estas proteínas não estruturais demonstrou que o NSm é dispensável para a replicação do vírus em células de mamíferos e mosquitos, ao passo que NSs é um importante gene de virulência, atuando como um antagonista de interferão tipo I (IFN) (TILSTON-LUNEL et al., 2015b).

A

Oropouche strain BeAn19991

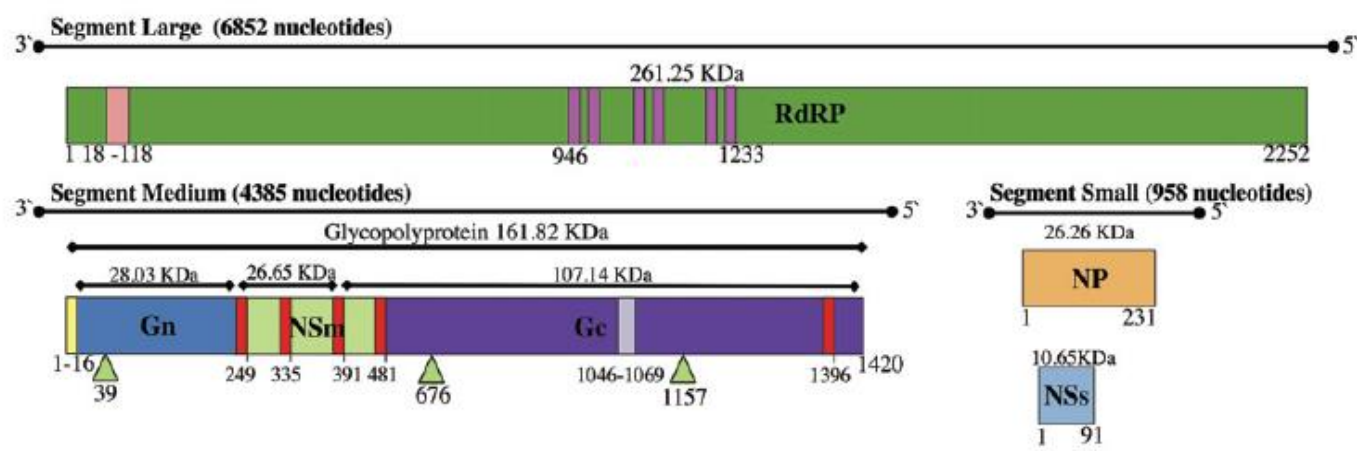

B

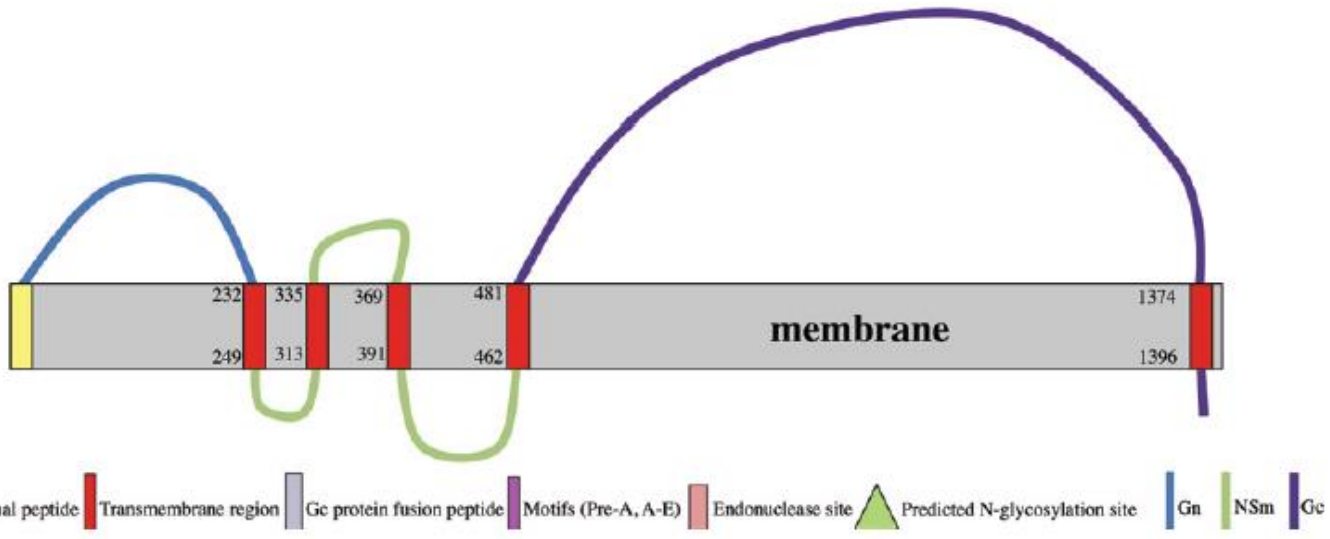

Figura 1. Representação esquemática da organização genômica (a) e topologia (b) da glicoproteína cepa BeAn 19991 do vírus de Oropouche. 
A ciclo de replicação nos Orthobunyavirus começa com a ligação viral aos receptores do hospedeiro, que é mediada por uma ou ambas as glicoproteínas virais (Gc e Gn), seguida pela internalização do vírus através da endocitose mediada pelo receptor (Figura 2). A acidificação de vesículas endocíticas leva ao desnudamento do virion e à fusão da membrana viral com a membrana endossomal. A ARN polimerase dependente de ARN viral (RdRp) catalisa a transcrição primária de mARN virais, que são iniciados por iniciadores derivados de células hospedeiras. Após a tradução dos mARNs virais, as glicoproteínas Gn e Gc dimerizam na ER e localizam-se ao complexo de Golgi utilizando um sinal no domínio transmembrana em Gn. Os três segmentos de genoma viral de sentido negativo (ARN genómico (gARN)) são convertidos em antigenomas de sentido positivo (ARN antigenómico $(\operatorname{ag} A R N)$ ) para a replicação do genoma na fábrica de vírus. As ribonucleoproteínas (RNPs) são então transportadas para membranas do complexo de Golgi que foram modificadas pela inserção de $\mathrm{Gn}$ e $\mathrm{Gc}$, e partículas de vírus brotam em vesículas derivadas de membrana de Golgi. As vesículas de Golgi que contêm partículas de vírus trafegam para a superfície celular e a fusão das membranas vesiculares com a membrana plasmática conduz à libertação de viriões infecciosos, que podem ser facilitados por filamentos de actina. As partículas virais nascentes são subsequentemente libertadas da célula (ELLIOTT, 2014).

Detalhes do ciclo de replicação de OROV são pouco conhecidos. A produção de progênies é observada 10 horas após a inoculação do vírus em células HeLa, com um pico após 24 horas. A interação entre a partícula de vírus e o receptor de célula é provavelmente mediada pelas glicoproteínas de superfície Gn e Gc. O vírus entra em células HeLa por endocitose mediada por vesículas revestidas com clatrina, enquanto a libertação de partículas virais do endossoma é dependente de acidificação endossomal (ACRANI et al., 2010).

Um efeito citopático importante observado após a replicação de OROV em células HeLa é consequente à indução do apoptose, que foi detectada às 36 horas após a infecção (ACRANI et al., 2010). A liberação de citocromo C e a ativação das caspases 9 e 3 foram detectadas e a apoptose ocorre sem afetar a carga viral, indicando que ela pode ser importante durante o ciclo de replicação do OROV. O mesmo trabalho sugeriu que a 
síntese de proteínas virais é necessária para a indução do apoptose, indicando que uma ou mais proteínas virais podem estar envolvidas neste mecanismo.

Estudos realizados por Medonça (2014), fornecem uma caracterização inicial do ciclo replicativo de OROV e sugerem que o complexo de Golgi não e o principal local de brotamento de OROV e a infecção por OROV ocasiona o deslocamento TGN46 para as fabricas virais, possivelmente OROV utiliza regiões do reticulo endoplasmatico para formar virions, e provavelmente não depende da atividade de Vps4A para formação de partículas virais.

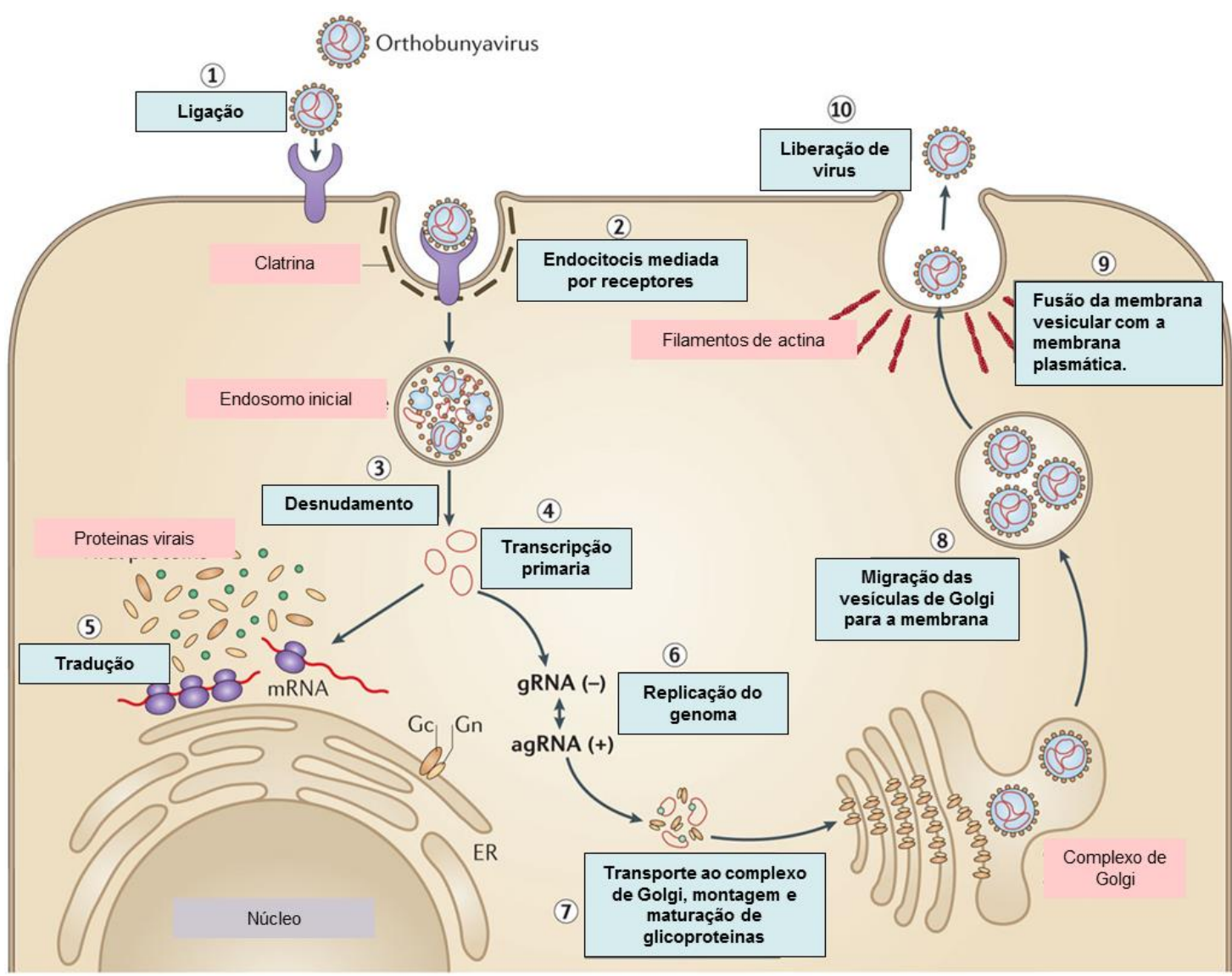

Figura 2. Esquema representando o ciclo de replicação do Orthobunyavirus. Adaptado de Elliot (2014). 


\subsection{Estratégias vacinais voltadas para o controle do OROV}

Apesar da importância epidemiológica do OROV, até o momento, não existe uma vacina ou um tratamento específico disponível. Os primeiros protótipos de vacinas, até o momento, foram baseados em OROV inativado por métodos químicos como detergentes, ou por fixação com paraformaldeído. Entretanto, nenhuma das preparações foi capaz de reduzir a carga viral, ou de induzir a produção de anticorpos neutralizantes. Um outro importante fator que dever ser considerado em vacinas de vírus atenuado é o risco do fenótipo ser alterado pelos processos de inativação (RODRIGUES et al., 2011). O ensaio de partículas vírus-like desenvolvido para este vírus (ACRANI et al., 2015; TILSTON-LUNEL et al., 2015c) poderia também ser utilizado como uma ferramenta para gerar uma potencial vacina recombinante.

\subsection{Modelos experimentais para o estudo da febre de Oropouche}

Com ausência de mortes registradas, pouco se sabe sobre a patogênese de infecções naturais por OROV. Seres humanos apresentam sintomas sistêmicos, com viremia detectada nos primeiros 2-4 dias do início dos primeiros sintomas. Em alguns pacientes, o vírus foi recuperado do líquido cefalorraquidiano, mas a via de invasão do SNC é desconhecida (PINHEIRO; TRAVASSOS DA ROSA; VASCONCELOS, 1996).

Estudos utilizando modelos animais têm ajudado a elucidar alguns aspectos da patogênese da OROV. Em 1978, Araujo e outros demonstraram que os vírus podiam ser detectados em lesões hepáticas com necrose significativa de hepatócitos e hipertrofia considerável de células de Kupffer 6 horas após o OROV foi inoculado intracerebralmente em hamsters de 3 semanas de idade, sugerindo uma transmissão hematogênica do vírus a partir do cérebro para o fígado (ARAUJO et al., 1978)

Um modelo de infecção em hamsters utilizando vírus inoculados pela via s.c. demonstrou a ocorrência de infecção sistêmica, com alta carga viral no plasma, que pode atingir um pico de $10^{6,0}$ TCID50/mL no terceiro dia após a infecção (ARAUJO et al., 1978; SANTOS et al., 2014). Neste modelo, Tanto os tecidos do cérebro como do fígado 
demonstraram lesões histológicas, com a detecção de vírus em títulos elevados e imunohistoquímica positiva mostrando a presença de antígenos virais nos neurônios (SANTOS et al., 2012, 2014).

A patogênese da infecção por OROV também foi estudada em modelos murinos. camundongos neonatos $\mathrm{BALB} / \mathrm{c}$ inoculados pela via s.c., apresentaram sinais clínicos no $5^{\circ}$ dia após a inoculação. Os animais apresentaram alta concentração de vírus replicante no cérebro, com inflamação das meninges e apoptose dos neurônios, aparentemente sem encefalite (SANTOS et al., 2014). Esses dados confirmaram o neurotropismo deste vírus. O acesso ao CNS foi revelado pela imunohistoquímica, que mostrou infecção por OROV avançando das partes posteriores do cérebro em direção ao prosencéfalo. OROV atinge as rotas neurais durante as primeiras fases da infecção, atingindo a medula espinhal e ascendendo ao cérebro através de regiões do tronco cerebral, com pouca inflamação. Durante os últimos períodos do ciclo infeccioso, o vírus atravessa a barreira hematoencefálica, disseminando-se no parênquima cerebral, com manifestações graves de encefalite (SANTOS et al., 2014).

Estudos baseados em inoculações subcutâneas de OROV em camundongos C57BL/6 imunocomprometidos de tipo selvagem e mutado revelaram que a indução da via de IFN de tipo I através de MAVS, IRF-3, IRF-7 e IFNAR é essencial para controlar a infecção por OROV e isso provavelmente ocorre predominantemente em células não mióides (PROENCA-MODENA et al., 2015). Além disso, o IRF-5 é um componente chave da resposta imune contra ortobunyavirus e tem um papel na modulação da resposta antiviral em tecidos periféricos, enquanto contribui para inibir o processo de neuroinvasão.

\subsection{Perspectivas e principais desafios para o desenvolvimento de una vacina eficaz contra a febre de Oropouche.}

Ainda não existe uma vacina eficiente e segura para o controle da febre de Oropouche. Para isso, ainda falta conhecimento sobre a patogênese das infecções pelo vírus. Isto lança preocupações sobre a segurança de vacinas baseadas em vírus atenuado. Neste sentido, a utilização de antígenos recombinantes oferece vantagens para o desenvolvimento de vacinas, por serem semelhantes ao vírus, não infectivas, baratas e 
altamente específicas (SAEED et al., 2001; FURTADO, 2007). São exemplos disso: a vacina de HBsAg recombinante para o vírus de hepatite B $(\mathrm{HBV})$, que é segura e eficiente (NATHANSON; KATZE; NATHANSON, 2007); e as duas vacinas contra papilomavirus humano (HPV), baseadas em VLP da proteína L1 viral mostrando-se eficientes e seguras (KIM et al., 2014).

A proteína $\mathrm{N}$ dos Orthobunyavirus, além de proteger o genoma viral, também, facilita a formação da estrutura panhandle do RNA, que acompanha o genoma viral, com um papel importante na replicação viral. A proteína $\mathrm{N}$ é o mais abundante produto encontrado em virions e em células infectadas (FIELDS; HOWLEY; KNIPE, 2007; MIR; PANGANIBAN, 2006) e também, o principal antígeno dos Orthobunyavírus, estimulando uma resposta humoral vigorosa, com produção de altos níveis de anticorpos IgG e IgM específicos (ELLIOTT, 2014; LEONARD et al., 2005; OSBORNE; ELLIOTT, 2000; SCHWARZ et al., 1996; ZOLLER et al., 1993). O desenvolvimento de uma vacina segura e efetiva, capaz de induzir proteção contra as infecções pelo OROV, será um relevante passo no controle deste importante arbovirose.

\subsection{Perspectivas e principais desafios para o desenvolvimento de una vacina eficaz contra a febre de Oropouche.}

Ainda não existe uma vacina eficiente e segura para o controle da febre de Oropouche. Uma vacina ideal contra o OROV. No entanto, a falta de conhecimento mais solido sobre a patogênese do vírus e dos mecanismos lança preocupações sobre a segurança das vacinas baseadas em vírus atenuado. Neste sentido, a utilização de antígenos recombinantes oferece diversas vantagens para o desenvolvimento de vacinas, por serem semelhantes ao vírus, não infetivas, baratas e altamente específicas (SAEED et al., 2001; FURTADO, 2007). São exemplos disso: a vacina de HBsAg recombinante para o vírus de hepatite B (HBV), que é segura e eficiente (NATHANSON; KATZE; NATHANSON, 2007); as duas vacinas contra papilomavirus humano (HPV), são baseadas na purificação da VLP da proteína L1 viral e tem se mostrado eficientes e seguras (KIM et al., 2014)

A proteína $\mathrm{N}$ dos Orthobunyavirus, além de proteger o genoma viral, também, facilita a formação da estrutura panhandle do RNA, que acompanha o genoma viral, com 
um papel importante na replicação viral. A proteína $\mathrm{N}$ é o mais abundante produto encontrado em virions e em células infectadas (FIELDS; HOWLEY; KNIPE, 2007; MIR; PANGANIBAN, 2006) e também, o principal antígeno dos Orthobunyavírus, estimulando uma resposta humoral vigorosa, com produção de altos níveis de anticorpos IgG e IgM específicos (ELLIOTT, 2014; LEONARD et al., 2005; OSBORNE; ELLIOTT, 2000; SCHWARZ et al., 1996; ZOLLER et al., 1993).

\section{JUSTIFICATIVA}

Considerando que o OROV produz frequente infecção humana e epidemias, estas com impacto econômico-social principalmente na América do Sul, e que, apesar disso, não tem um modelo murino em adultos para testar vacinas, e a doença não dispõe de profilaxia vacinal ou tratamento específico. O desenvolvimento de uma vacina protetora contra tais infecções usando como imunógeno a proteína NrOROV seria um importante passo para o controle desta arbovirose. 


\section{OBJETIVOS}

Objetivou-se com este trabalho avaliar a resposta imune conferida pela proteína do Nucleocapsídeo do vírus Oropouche utilizando para tanto um modelo murino de infecção viral.

\section{Objetivos específicos}

- Pesquisar por um modelo de infecção por OROV em camundongos Swiss e Balb/c, de diferentes idades e utilizando distintas vias de inoculação;

- Avaliar a resposta humoral induzida pela imunização dos animais com a proteína NrOROV;

- Determinar a capacidade protetora da imunização com a proteína rNOROV com base na sobrevida dos camundongos desafiados com OROV. 


\section{MATERIAL E MÉTODOS}

\subsection{Técnicas laboratoriais}

\subsubsection{Vírus Oropouche (OROV)}

A cepa BeAn19991 de OROV, gentilmente cedida pela Dra. Amélia Travassos da Rosa ao banco de vírus do Centro de Pesquisa em Virologia (CPV-FMRP-USP), foi propagada em monocamadas de células C6/36 e in vitro em cérebro de camundongos recémnascidos. Para tanto, monocamadas de células de mosquito Aedes albopictus do clone C6/36 foram mantidas em meio Leibowitz L-15 (GIBCO, USA) contendo 10\% de soro fetal (SBF) inativado pelo calor, $10 \%$ de caldo de triptose fosfato, $100 \mathrm{U} / \mathrm{ml}$ de penicilina e $0,1 \mathrm{mg} / \mathrm{ml}$ de estreptomicina, are $28^{\circ} \mathrm{C}$ em estufa comum (FIGUEIREDO, 1990). Estas células foram infectadas com OROV e 5 dias após infecção foram coletadas os sobrenandantes e alíquotadas. OROV foi propagado em cérebro de camundongo recém nascidos (Mus musculus, da variedade albino suíço), com 1 ou 2 dias de vida. $O$ procedimento consistiu na inoculação intracerebral e o sacrifício dos animais assim que apresentam sinais de encefalite, o que ocorreu 48 horas após infecção, os cérebros removidos por punção a vácuo diluídos em MEM (Gibco/Invitrogen, USA) com 2\% de soro fetal bovino inativado (Gibco/Invitrogen, USA), na seqüencia todo material obtido foi centrifugado a $5445 \mathrm{x}$ g por 10 minuto a $4^{\circ} \mathrm{C}$. $\mathrm{O}$ sobrenadante foi filtrado em poros de $0.22 \mu \mathrm{m}$ (Millipore, USA), alíquota e congelado em freezer a $-80^{\circ} \mathrm{C}$.

Os estoques virais de OROV tiveram a infecção confirmada por testes de imunofluorescência e/ou RT-PCR e foram quantificados em unidades formadoras de plaques (PFU). Também, estas técnicas foram utilizadas nos experimentos relacionados ao desenvolvimento do modelo experimental e dos testes vacinais. Ainda, os soros dos animais imunizados foram submetidos a testes sorológicos para pesquisa de anticorpos contra OROV. 


\subsubsection{Teste de Imunofluorescência Indireta (IFA)}

A infecção celular por OROV foi confirmada pela detecção de antígenos virais utilizando IFA. Para tanto, as células supostamente infectadas com OROV foram transferidas para spots de lâminas de imunofluorescência (Perfecta, Brasil). Após secagem ao ar livre as células foram fixadas em acetona gelada e posteriormente adicionou-se aos spots fluido ascítico hiperimune (MIAF-Mouse immune ascitic fluid) anti-OROV do banco de anti-soros do CPV-FMRP-USP (LENNETE; SCHMIDT, 1979). Em seguida, as lâminas foram lavadas com PBS ( $\mathrm{pH} \mathrm{7,2),} \mathrm{por} 5$ min e incubadas com anticorpo (secundário) de origem caprina anti-imunoglobulina de camundongo conjugado com isotiocianato de fluoresceína (FITC) (Sigma, USA), as lâminas foram secas e analisadas ao microscópio de fluorescência (Olympus, Japão).

Para teste dos soros de animais imunizados por IFA, células HeLa foram cultivadas sobre lamínulas de vidro de $13 \mathrm{~mm}$ de diâmetro (Knittel Glase, Alemanha) colocadas em placas de 24 poços e infectadas com OROV. Lavaram-se as células, 24 horas após infecção, por 3 vezes, com PBS e estas foram fixadas às lamínulas, por 15 minutos, à temperatura ambiente (TA), com solução de paraformaldeído (PFA) a 4\% (Sigma AldrichEUA) diluído em PBS. Em seguida, lavaram-se as células por 5 vezes com PBS e estas foram permeabilizadas, durante 10 minutos à TA, com solução de Triton X-100 (SigmaAldrich, EUA) a 0,1\% diluído em PBS. Todas as células foram lavadas com PBS e sítios inespecíficos foram bloqueados, por $30 \mathrm{~min}$, à $37^{\circ} \mathrm{C}$, com gelatina porcina a $0,2 \%$ (SigmaAldrich, EUA) em PBS suplementado com azida sódica a 0,02\%. A seguir, as células foram incubadas com soros dos grupos de camundongos imunizados, diluídos na solução de bloqueio, por $30 \mathrm{~min}$, à $37^{\circ} \mathrm{C}$, em câmara úmida. Em continuação, lavaram-se as lamínulas por 5 min em PBS e estas foram incubadas com anticorpos secundários ALEXA 488, na diluição 1:1000, com o corante DAPI 300nM (Molecular Probes, Invitrogen-EUA). Ao final, lavaram-se as lamínulas por 5 minutos em PBS e estas foram montadas sobre lâminas de vidro com Fluoromount G (EM Sciences-EUA). Em laminas de microscopia, seladas e estocadas a $4^{\circ} \mathrm{C}$. Em seguida o material foi examinado e imagens foram adquiridas em microscópio de fluorescência Modelo BX40 (Olympus, EUA). 


\subsubsection{Reação em cadeia pela polimerase precedida de transcrição reversa (RT - PCR) Extração de RNA}

Fez-se a extração do RNA dos estoques virais, soros e tecidos dos camundongos utilizando o kit QIAamp Viral RNA Mini Kit, seguindo as instruções do fabricante (Qiagen, Alemanha). Os extratos de RNA foram eluídos em $60 \mu 1$ de água livre de RNAse e armazenados a $-80^{\circ} \mathrm{C}$.

RT - PCRs dos segmentos S, M e L do RNA de OROV - Extratos de RNA foram submetidos a RT-PCR amplificando os segmentos S, L e M do OROV. Primeiramente, fez-se transcrição reversa (RT) com a enzima SuperScript III First-Strand Synthesis System (Invitrogen, EUA) e em seguida a PCR utilizando a Platinum Taq DNA Polymerase High Fidelity (Invitrogen, EUA), em ambos os casos, seguindo as orientações dos fabricantes. Foram utilizados os primers mostrados na Tabela 1, e a mistura de reação na tabela 2. No teste, utilizaram-se 30 ciclos térmicos. Iniciando por $94^{\circ} \mathrm{C}$ por 2 minutos (min) seguidos de 30 ciclos a $94^{\circ} \mathrm{C}$ por 30 segundos (seg) para desnaturação das cadeias de DNA; $56^{\circ} \mathrm{C}$ por 30 seg para anelamento dos primers e $72^{\circ} \mathrm{C}$ por 1 min para extensão das novas cadeias de DNA. Ao final promovia-se uma extensão a $72^{\circ} \mathrm{C}$ por $5 \mathrm{mim}$. Os produtos de amplificação (amplicons) foram submetidos a eletroforese em gel de agarose a 1,5\% e os géis, corados por neutral-red, foram visualizados em foto-documentador (Alphalmager, Alpha Innotech). Também, amplicons tiveram seus nucleotídeos sequenciados para confirmação da origem viral. (Arruda et al, dados não publicados).

Tabela 1. Primers utilizados na PCR de OROV.

\begin{tabular}{l|l|l}
\multicolumn{1}{c|}{$\begin{array}{c}\text { Segmento M de OROV } \\
\text { Produto de 818bp }\end{array}$} & \multicolumn{1}{|c}{$\begin{array}{c}\text { Segmento L de OROV } \\
\text { Produto de 451bp }\end{array}$} & \multicolumn{1}{c}{\begin{tabular}{c}
\multicolumn{1}{c}{ Segmento S de OROV } \\
Produto de 306bp
\end{tabular}} \\
\hline Forward: & Forward: & Forward: \\
5'- & 5'- & 5'- \\
TGCATGCTTTAGACAACATAG & TTAGTATGCAATGGTTTTTTG & TCAATGCTGGTGTTGTTAGAG \\
Região: 559 a 583 & Região: 504 a 524 & Região: 145 a 165 \\
& & Reverse: \\
Reverse: & Reverse: & 5'- \\
5'- & 5'- & TCACCATCATTCCAAGTACAG \\
TCTTTCTGGACATGCATATCC & ATGCATGCTTGGTTTTTCCTG & Região: 431 a 451 \\
Região: 1357 a 1377 & Região: 935 a 955 & \\
\hline
\end{tabular}


Tabela 2. Reagentes para mistura de reação da PCR para OROV.

\begin{tabular}{c|c}
\hline & $\begin{array}{c}\text { Reacao } \\
1 \mathrm{x}(\mathrm{ul})\end{array}$ \\
\hline Buffer 10x & 2.5 \\
\hline $\mathrm{MgCl} 50 \mathrm{MM}$ & 0.75 \\
\hline $\mathrm{dNTP}$ mix mM & 0.5 \\
\hline $\begin{array}{c}\text { Enzima taq } \\
\text { polimerasa }\end{array}$ & 0.1 \\
\hline Primer Reverse & 0.5 \\
\hline Primer Forward & 0.5 \\
\hline Template DNA & 3 \\
\hline Agua & 3 \\
\hline Total & $25 \mathrm{ul}$ \\
\hline
\end{tabular}

\subsubsection{Seqüenciamento nucleotídico de amplicons pelo método de Sanger}

Para seqüenciar os amplicons dos segmentos $\mathrm{S}$ e L de OROV, utilizou-se o seqüenciamento pelo método de Sanger com adaptações (SANGER; NICKLEN; COULSON, 1992). As reações de seqüenciamento foram preparadas utilizando o reagente BigDye Terminator Cycle Sequencing Ready Reaction v3.1 (Applied Biosystems, EUA) em reação com volume final de $20 \mu \mathrm{L}$, contendo $2 \mu \mathrm{L}$ de BigDye, $5 \mathrm{pM}$ de oligonucleotídeo e $200 \mathrm{ng}$ de produtos de PCR purificados. As reações foram incubadas por 1 min a $95^{\circ} \mathrm{C}$ e submetidas a 35 ciclos com desnaturação das cadeias de DNA a $95^{\circ} \mathrm{C}$ por $10 \mathrm{seg}$, anelamento dos oligonucleoídeos a $50^{\circ} \mathrm{C}$ por $15 \mathrm{seg}$, e extensão das novas cadeias de DNA a $60^{\circ} \mathrm{C}$ por 4 minutos. Após a reação de seqüenciamento as amostras foram precipitadas pela adição de isopropanol $65 \%$ e incubada a temperatura ambiente por $20 \mathrm{~min}$. Em seguida as amostras foram centrifugadas a 2000 x $g$ por $45 \mathrm{~min}$ a $4^{\circ} \mathrm{C}$. O sobrenadante foi descartado e foram adicionados $200 \mu \mathrm{L}$ de etanol $70 \%$ e após incubação por 2 min à temperatura ambiente, procedeu-se a nova centrifugação a 2000 x $g$ por 10 min a $4^{\circ} \mathrm{C}$. O sobrenadante foi removido e o excesso de etanol evaporado por 30 min em estufa a $37^{\circ} \mathrm{C}$. O DNA precipitado foi solubilizado em solução tampão de formamida hidi (Applied Biosystems, EUA) e analisado no seqüenciador automático ABI 3500 (Applied Biosystems, EUA). 


\subsubsection{Teste de plaques para quantificação dos estoques virais, fluidos e tecidos dos animais}

Os estoques virais, bem como materiais séricos e de tecidos dos camundongos foram quantificados por ensaio de plaques com células Vero infectadas (RUSSELL; NISALAK, 1967). Estas células foram mantidas em meio E-MEM (EARLE - Minimum Essential Medium), suplementado com $10 \% \mathrm{SBF}$ e incubadas a $37^{\circ} \mathrm{C}$, em atmosfera úmida contendo $5 \%$ de $\mathrm{CO}_{2}$. As células eram infectadas com diluições decimais dos materiais. Após 5 dias de incubação as células foram fixadas e coradas e determinava-se o número de unidades formadoras de plaques (PFU)/grama.

Também, calculou-se o correspondente título de OROV em PFU por grama de tecido usando a seguinte equação:

$$
\frac{\# \text { PFU poço } 1+\# \text { PFU poço } 2}{0.2 \text { ml volume total } *} \times \text { factor de diluição } \times \frac{1.5 \mathrm{ml} \text { DMEM } M^{\mathrm{w}}}{0.15 \mathrm{~g} \text { tecido }}=P F U / \text { grama de tecido }
$$

*0.2 ml volume total: $100 \mathrm{ul}$ de amostra inoculada nos poços em duplicata $=100 \mathrm{ul}+100 \mathrm{ul}$. ${ }^{\mathrm{w}}$ fator de diluição do processamento do tecido.

\subsubsection{Teste de neutralização por redução de plaques $(\mathrm{PRNt})$}

Anticorpos neutralizantes contra OROV foram detectados por PRN utilizando técnica descrita por (RUSSELL; NISALAK, 1967), com pequenas modificações. Após inativação do complemento a $56^{\circ} \mathrm{C}$ por $40 \mathrm{~min}$ e os soros sofreram diluições decimais e foram incubados a $37^{\circ} \mathrm{C}$, por uma hora, com 88 PFU de OROV para que ocorresse a neutralização. Em seguida, as misturas vírus-soro foram inoculadas em monocamadas de células Vero contidas em placas de 24 poços, incubando-se por uma hora, a $37^{\circ} \mathrm{C}$. Em seguida, removeu-se o fluido sobrenadante, a monocamada celular foi lavada com PBS e recoberta com meio semi-sólido (meio DMEM suplementado com 10\% de soro bovino fetal acrescido de solução semi-sólida contendo 3\% de carboximetilcelulose. As placas foram incubadas a $37^{\circ} \mathrm{C}$, em $5 \% \mathrm{CO}_{2}$ por 5 dias e em seguida a monocamada de células foi fixada com $10 \%$ de formaldeído em PBS, por uma hora e posteriormente corada com preto de naftaleno. O título de anticorpos neutralizantes foi determinado como a maior diluição 
do soro que reduz em $50 \%$ o número de plaques visualizadas em comparação a uma titulação com vírus puro.

\subsubsection{Ensaio imuno-enzimático para pesquisa de anticorpos contra OROV utilizando células infectadas como antígeno (EIA-ICC)}

EIA-ICC- A presença de anticorpos contra OROV foi pesquisada por um ensaio imunoenzimático utilizando células infectadas como antígeno (EIA-ICC). Para tanto, prepararamse microplacas de 96 orifícios com células C6/36 oriundas de frascos de $75 \mathrm{~cm}^{2}$ infectadas com OROV. Outros frascos foram mantidos com células não infectadas, para serem utilizadas como controles negativos do teste. Os frascos foram incubados a $28^{\circ} \mathrm{C}$ por 5 dias. Para o preparo das microplacas, as células contidas nos frascos foram raspadas, foram rompidos grumos celulares por pipetagem e as células foram contadas em câmara de Neubauer. Um número de 100.000 células por $100 \mu \mathrm{l}$ do meio de cultivo com $2 \%$ de SFB foi adicionado a cada orifício de microplacas estéreis de poliestireno com 96 orifícios de fundo chato (Corning, EUA). Adicionaram-se células infectadas ou não infectadas a metade das placas. As microplacas foram levemente agitadas para que as células se depositassem homogeneamente ao fundo dos orifícios e estas foram incubadas por uma noite, em ambiente úmido, a $28^{\circ} \mathrm{C}$. Em seguida, as células das placas foram fixadas ao fundo dos orifícios pela adição de $100 \mu \mathrm{l}$ de solução de formalina tamponada a $10 \%(10 \%$ de formaldeído em 100ml de água, 6,5 g de fosfato de sódio dibásico anidro, $4 \mathrm{~g}$ de fosfato de sódio monobásico e água destilada q.s.p.900ml, pH 7,4). Em continuação, as placas foram incubadas por 12 a $18 \mathrm{~h}$, em atmosfera úmida, a $4^{\circ} \mathrm{C}$, tiveram os orifícios lavados por 5 vezes com solução de Tween, 1/20000 em PBS (PBS-T) e secos por emborcamento sobre papel absorvente. Estas microplacas, prontas para uso, foram utilizadas imediatamente ou, colocadas em recipiente plástico e armazenadas a -20C (FIGUEIREDO et al., 1987-1989) (LIMA; FIGUEIREDO et.al., 2007).

ELISA de NrOROV - Placas com 96 poços foram sensibilizadas a metade com NrOROV e a outra metade com extrato de E. coli, diluídos em tampão carbonato-bicarbonato e incubadas a $4^{\circ} \mathrm{C}$ overnight, Em seguida as placas foram lavadas 5 vezes com PBS contento 
$0.05 \%$ de Tween 20 (PBS-T), logo foram bloqueadas com 10\% de leite e incubadas por 1 hora e lavadas com PBS-T (SAEED et al., 2001).

Para EIA-ICC e Elisa de NrOROV, amostras de soro de camundongos imunizados em diferentes diluições foram testados e adicionados aos poços, estas foram incubadas por $1 \mathrm{~h}$ a $37^{\circ} \mathrm{C}$ e lavadas com PBS-T. Em seguida, adicionou-se aos orifícios imunoglobulina caprina anti-IgG de camundongo conjugada à enzima peroxidase (Sigma-Aldrish, EUA). Novamente, as placas foram incubadas por $1 \mathrm{~h}$ a $37^{\circ} \mathrm{C}$ e lavadas com PBS-T. Ao final, adicionou-se o substrato ABTS que, ao se oxidar, adquire cor verde. A cor nos orifícios foi lida visualmente e também, em espectrofotômetro leitor de placas de ELISA (Titertek, Finlândia) com filtro de $405 \mathrm{~nm}$. O cálculo do ponto de corte (cut-off) foi feito com base na média das densidades óticas (DO) obtidas no espectrofotômetro em pelo menos 8 orifícios contendo células não infectadas. A esta média acrescentou-se 3 desvios-padrão determinando ao teste uma especificidade $>99 \%$. Valores acima do ponto de corte foram considerados positivos.

\subsubsection{Dose letal para 50\% (LD50) dos camundongos Balb/c adultos}

Determinou-se a dose letal $50 \%\left(\mathrm{LD}_{50}\right)$ a ser utilizada no desafio dos camundongos imunizados com NrOROV do modelo experimental. Para tanto, grupos de camundongos foram anestesiados e inoculados, pela via i.c., com diferentes diluições decimais da semente de OROV. Os animais foram acompanhados por 12 dias e ao final avaliada a letalidade produzida pelo inóculo viral nas diferentes diluições o que permitiu determinar a $\mathrm{LD}_{50}$ nestes camundongos adultos pelo método de Reed \& Muench, 1938.

\subsubsection{Hemograma dos camundongos}

Realizou-se hemograma dos camundongos imunizados manualmente. Para tanto, 0.8 $\mathrm{ml}$ de sangue foram coletados em microtubos contendo 0.37 M de EDTA. Determinou-se hematócrito em microcapilares por centrifugação (3000 rpm por $5 \mathrm{mim}$ ), e contaram-se glóbulos brancos em câmara de Neubauer. A diferenciação de neutrófilos e linfócitos foi 
feita visualmente usando a fase de contraste do microscópio e o número de plaquetas foi determinado por método de Fonio.

\subsubsection{SDS-PAGE e Western Blot da proteína recombinante do Nucleocapsideo de OROV (NrOROV)}

Utilizamos a proteína NrOROV previamente sintetizada e purificada no CPV-FMRPUSP. (AQUINO, 2002). Quantidade maior de NrOROV foi sintetizada, purificada e disponibilizada por encomenda em empresa comercial (Nanocore, Brasil). Previamente aos experimentos, verificamos as amostras de NrOROV, separando as proteínas por SDSPAGE, sob condições desnaturantes e redutoras, e estes materiais foram submetidos a eletroforese vertical a $90 \mathrm{~V}$, em solução tampão de corrida eletroforética composto por 25mM de Trizma® base (Sigma-Aldrich, EUA), 190 mM de glicina (Sigma-Aldrich, EUA) e $0,1 \%$ de SDS. Em seguida, as proteínas foram eletro transferidas para membranas de nitrocelulose de 0,45 $\mu \mathrm{m}$ (Amersham Biosciences, GE Healthcare Bio-Sciences, EUA) que foram incubadas em solução de bloqueio contendo 5\% de leite em pó desnatado em PBS-T (PBS suplementado com 0,1\% de Tween 20 (Sigma-Aldrich, EUA) por 1 hora em agitação constante. Posteriormente, as membranas foram lavadas e incubadas com MIAF e/ou anticorpo primário monoclonal contra proteína de $\mathrm{N}$ de OROV e deixadas overnight a $4^{\circ} \mathrm{C}$, sob agitação. Em seguida, lavaram-se as membranas e estas foram incubadas com anticorpo secundário conjugado a HRP (Molecular Probes, EUA). Visualizaram-se as proteínas por luminescência em ChemicDoc (Bio-Rad, EUA), após tratamento com solução de ECL [0,1M de Tris-HCl pH 8,5, 1,25mM de Luminol (Sigma- Aldrich, EUA), 0,2mM de ácido cumárico (Sigma Aldrich, EUA) e 0,02\% de H2O2].

\subsection{Modelo experimental de infecção por OROV em camundongos}

Os camundongos utilizados neste trabalho foram manipulados seguindo o Protocolo para uso de animais em experimentação. $N^{\circ} 170 / 2014$, que foi aprovado pelo Conselho nacional de controle de experimentação animal (CONCEA). 
Utilizaram-se camundongos Swiss e Balb/c fêmeas de 3 e 6 semanas de idade, que foram inoculados pelas vias: intraperitoneal (i.p.), veia caudal (v.c), subcutânea (s.c) e intracerebral (i.c). Animais infectados pela via i.c. foram anestesiados com combinação de ketamina $(80 \mathrm{mg} / \mathrm{kg})$ e xilasina $(15 \mathrm{mg} / \mathrm{kg})$. No seguimento dos animais inoculados, por 15 dias, avaliou-se a sobrevida e a evolução de um score clínico.

\subsubsection{Coleta de órgãos e fluidos dos camundongos para quantificação de OROV}

Para quantificação do OROV em fluidos e órgãos dos camundongos Balb/c de 12 semanas foram inoculados pela via i.c., $8 \times 10^{5}$ PFU de OROV e submetidos em diferentes tempos pós-infecção, os animais foram anestesiados, perfundidos e sacrificados e deles coletaram-se amostras do cérebro, medula espinhal, baço, fígado, coração, pulmão, rins, Os órgãos foram pesados e armazenados em tubos côncavos contendo DMEM com 2\% se soro fetal bovino em peso (volume) equivalente ao peso do órgão. Os tubos foram armazenados a $-80^{\circ} \mathrm{C}$.

Posteriormente, as amostras de tecido foram descongeladas lentamente sobre gelo, adicionadas a beads metálicas em tubos para processamento em TissueLyser II (Qiagen) onde realizaram-se ciclos de homogeneização (à freqüência de oscilação de $30 \mathrm{~Hz}$ por 10 min). Após verificado o rompimento dos tecidos, centrifugaram-se os lizados a $14000 \mathrm{rpm}$ por 10 mim a $4^{\circ} \mathrm{C}$ e os sobrenadantes foram colhidos, desprezando-se o produto celular sedimentado. Esses sobrenadantes foram submetidos a diluições seriadas decimais, para o ensaio de plaques.

\subsubsection{Inóculos antigênicos contendo NrOROV e controles do experimento}

Para avaliar a imunogenicidade de NrOROV foram promovidos experimentos nos quais 6 diferentes grupos de 6 camundongos Balb/c foram imunizados com diferentes volumes (Tabela 3). Adjuvante completo de Freud (FCA) e Montanide ISA 720, não são licenciados para uso humano, mas foram usados para avaliar a autencidade da resposta imune da proteína recombinante viral. Todas os grupos que continham adjuvantes foram misturadas em seringa de vidro até obter uma emulsão. 
Tabela 3 - Grupos de animais submetidos aos experimentos de imunização com $\mathrm{NrOROV}$, segundo as diferentes preparações de imunógenos e incluindo os que receberam controles positivos e negativos.

\begin{tabular}{l|l}
\hline $\mathrm{N}$ & 20 ul de solução contendo apenas a proteína NrOROV* \\
\hline $\mathrm{N}+\mathrm{FCA}$ & $\begin{array}{l}\text { Mistura de } 20 \text { ul de NrOROV com } 20 \text { ul do adjuvante completo de } \\
\text { Freund. }\end{array}$ \\
\hline N+Mont+Poli & $\begin{array}{l}\text { Mistura de 20 ul de NrOROV com 55 ul de Montanide ISA720 e ainda 25 } \\
\text { ul de de Poli I:C }\end{array}$ \\
\hline OROV & \begin{tabular}{l}
50 ul de solução contendo apenas OROV (controle positivo) \\
\hline OROV+FCA \\
positivo)
\end{tabular} \\
\hline PBS & 100 ul de PBS (controle negativo) \\
\hline
\end{tabular}

*10 ug/20 ul da proteína NrOROV

\subsubsection{Protocolo de imunização com NrOROV e desafio dos animais com OROV}

Os 6 grupos de camundongos foram imunizados pela via s.c. no dia 0,14 , e 28 e foram desafiados, pela via i.c., com $10 \mathrm{LD}_{50}$ de OROV, no dia 42. Amostras de sangue pela veia da facial foram coletadas, para avaliar a resposta humoral, após cada imunização, exatamente nos dias 7, 21 e 35 .

\subsubsection{Avaliação da proteção conferida por NrOROV com base na sobrevida, peso e score clínico dos camundongos}

Após o desafio com $10 \mathrm{LD}_{50}$ de OROV pela via i.c., todos os grupos de animais foram acompanhados por 20 dias e foi avaliada a mortalidade dos mesmos, o peso e o score clínico referente a cada grupo. Dados obtidos foram plotados em gráfico utilizando o programa GraphPad Prism 5 (GraphPad Software) permitindo criar curvas de sobrevivência, peso e score clinico segundo os distintos grupos de animais.

\subsection{Análises estatísticas.}

Os testes foram calculados usando o programa GraphPad Prism 5 (GraphPad Software). Para análise de títulos virais, os títulos em log foram analisados por el teste de Mann-Whitney. A significância estatística foi considerada quando $\mathrm{p}<0,05$. 


\section{RESULTADOS}

\subsection{OROV}

Estoques de OROV produzidos em células C6/36 e coletados após 4 dias de infeção tiveram a presença viral evidenciada por IFA como mostrado na Figura 3, antígenos fluorescentes de OROV foram observados em mais de $90 \%$ das células.
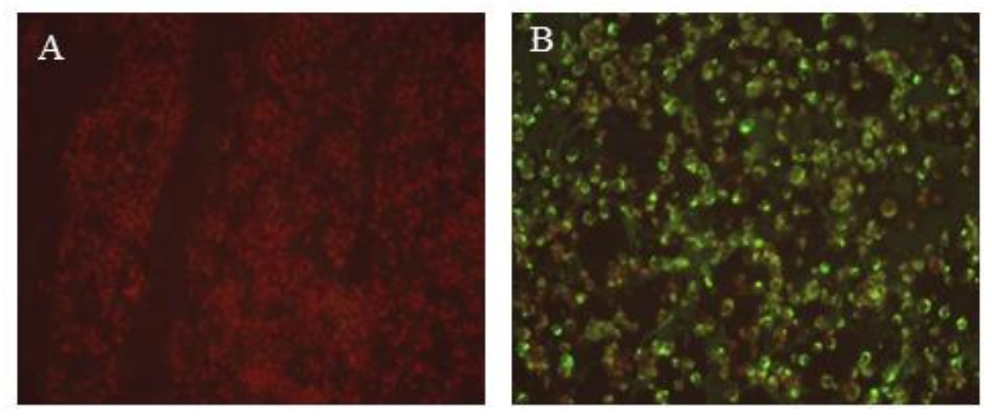

Figura 3. IFA para OROV em células C6/36 observadas com aumento de 40x. (A) Células não infectadas (controle negativo). Células infectadas com OROV evidenciando antígenos fluorescentes de OROV na maioria das células.

Também, o estoque de OROV preparado em células C6/36, teve a presença viral definitivamente confirmada por RT-PCR que amplificou os segmentos small (S), médium (M) e large (L) do genoma viral (Figura 4).

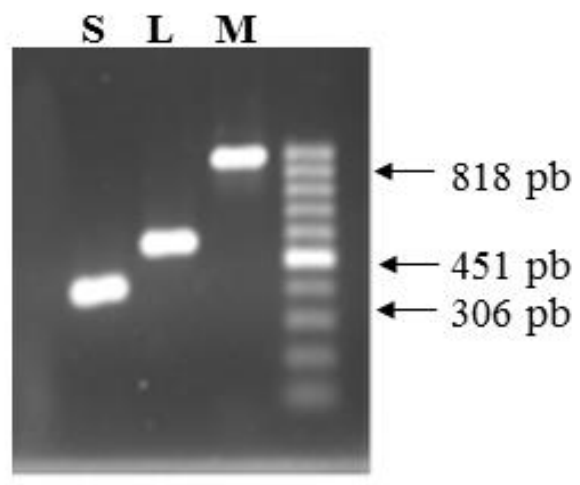

Figura 4. RT-PCR do estoque de OROV em células C6/36 evidenciando o vírus pela amplificação dos 3 segmentos do genoma viral: small $(\mathrm{S})$ com $\sim 306$ pares de bases $(\mathrm{pb})$, medium $(\mathrm{M})$ com $\sim 451 \mathrm{pb}$ e large $(\mathrm{L})$ com $\sim 818 \mathrm{pb}$.

Ainda, para uma confirmação definitiva da presença viral, nucleotídeos dos segmentos de $\mathrm{S}$ e L foram seqüenciados pelo método de Sanger e foi realizado o alinhamento 
local das seqüências no programa Blast N (NCBI), mostrando 99\% e 100\% de identidade, respectivamente, para a cepa BeAn19991 de OROV, como mostra a Figura 5.

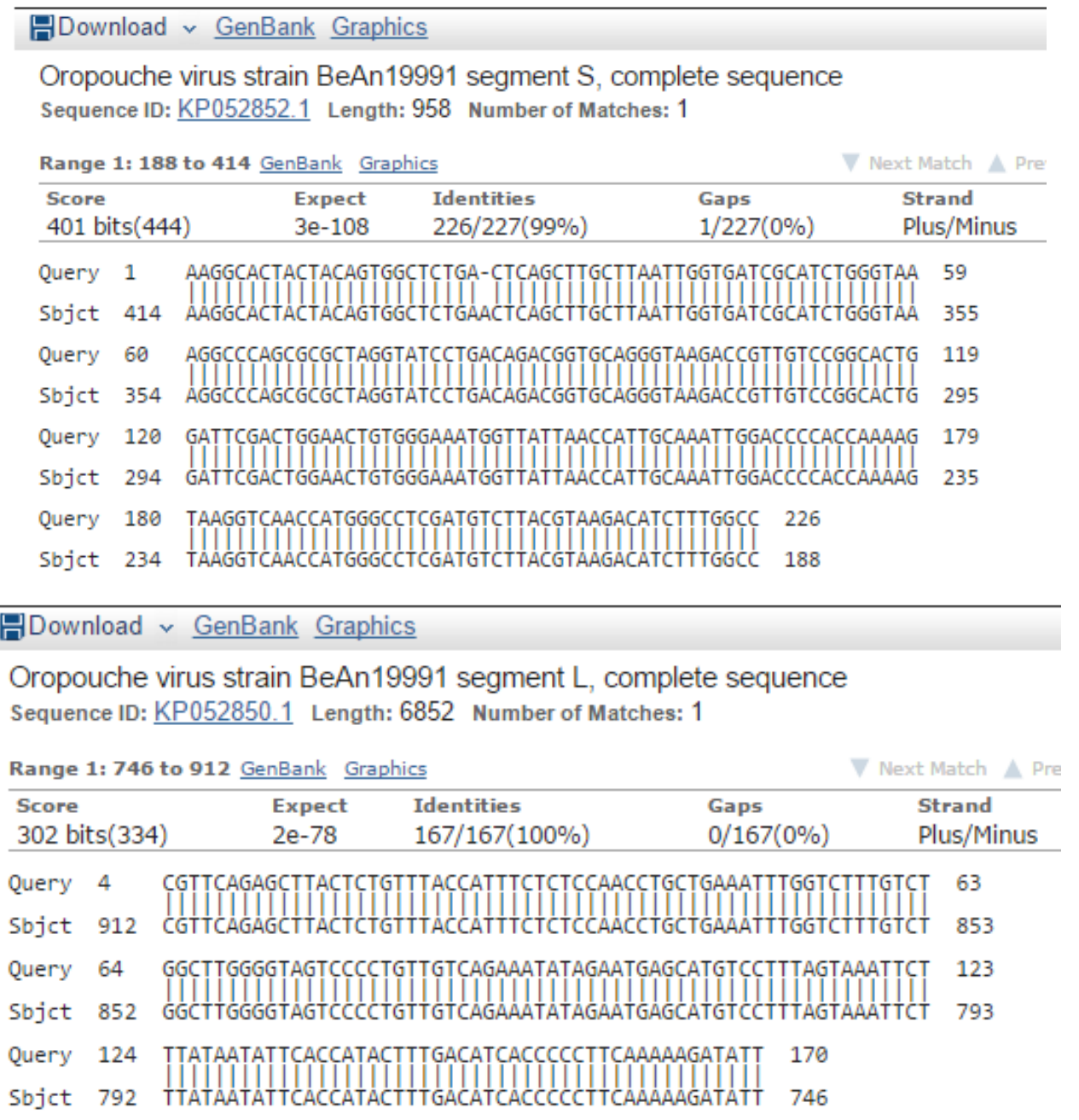

Figura 5. Sequiências nucleotídicas dos segmentos S e L de OROV, no programa Blast N (NCBI).

Confirmada a infecção, quantificou-se OROV em ensaio de plaques que evidenciou 8.5 $\times 10^{7} \mathrm{PFU} / \mathrm{mL}$. Quanto ao estoque de OROV preparado em camundongos recém nascidos, este título foi de $4 \times 10^{7} \mathrm{PFU} / \mathrm{mL}$. O estoque de OROV preparado em camundongos recém nascidos e com presença viral confirmada por RT-PCR seguida de seqüenciamento dos amplicons, mostrou resultado idêntico ao dos vírus em cultura de células e foi utilizado para desenvolver o modelo animal, bem como nos desafios dos animais previamente imunizados. 


\subsection{A proteína $\mathrm{N}$ recombinante do vírus Oropouche (NrOROV)}

A presença e qualidade antigênica das amostras de NrOROV foram analisadas por Western blot nas concentrações de $6 \mu \mathrm{g} / 12 \mu \mathrm{l}$ e $12 \mu \mathrm{g} / 24 \mu \mathrm{l}$. Por este método foi possível detectar de forma clara, com MIAF anti-OROV e anti-N, uma proteína de 26KDa pura (não haviam outras bandas quando reagia com anti-OROV). Esta banda, como mostra a Figura 6.

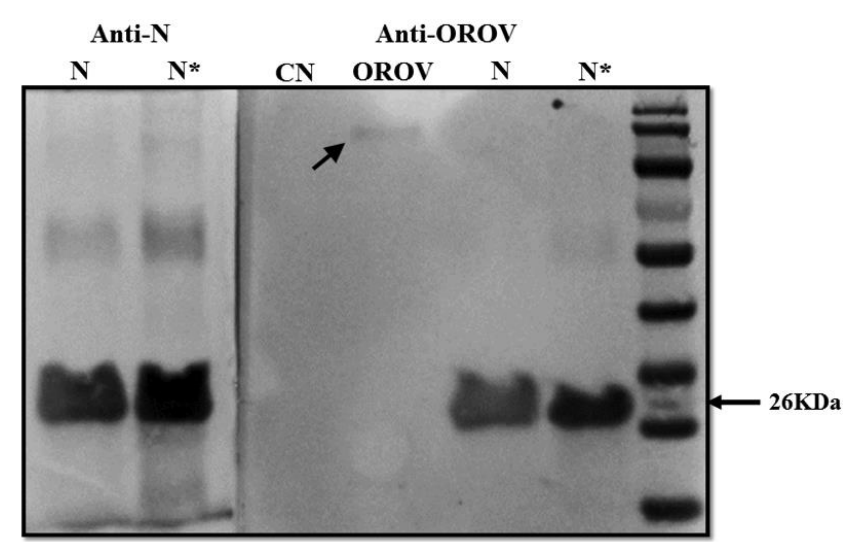

Figura 6. Western blot de amostras contendo $\mathrm{N}=6 \mu \mathrm{g} / 12 \mu \mathrm{l} \mathrm{e} \mathrm{N}^{*}=12 \mu \mathrm{g} / 24 \mu \mathrm{l}$. De NrOROV mostrando reatividade com anticorpos murinos.

\subsection{O modelo experimental de infecção por OROV em camundongos}

\subsubsection{Vias de inoculação do OROV}

Na pesquisa do modelo experimental, camundongos Swiss e Balb/c, de 3 e 6 semanas foram infectados com $3 \times 10^{6}$ PFU de OROV pela via i.p. e em veia, caudal, ou subcutânea. Em todos estes experimentos, observou-se sobrevida similar dos animais, entre 70 e $100 \%$. A maioria dos animais que morriam apresentaram pelo arrepiado, falta de equilíbrio, paralisia das patas e convulsões, sinais de doença evidenciados a partir do 4 dia pósinfeção. Por outro lado, animais inoculados com $3 \times 10^{6}$ PFU OROV pela via i.c., tiveram $100 \%$ de letalidade, morrendo entre o $3^{\circ}$ e o $5^{\circ}$ dia pós-infecção, mostrando falta de equilíbrio, paralisia das patas e convulsões seguidas da morte. Figura 7. 

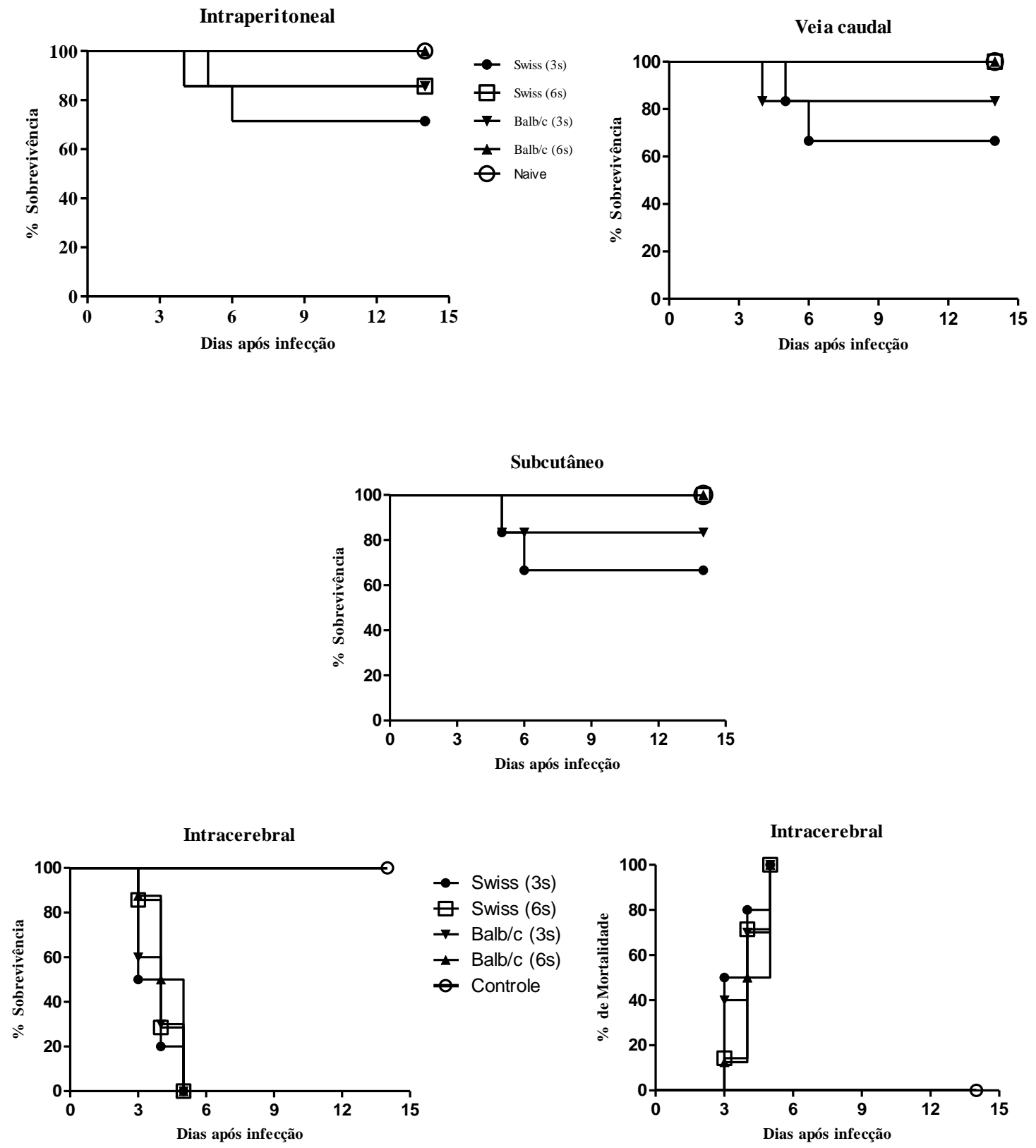

Figura 7. Porcentual de sobrevida de camundongos infectados com OROV por diferentes vias de inoculação.

Ao final, decidimos escolher para modelo animal de OROV a linhagem Balb/c por ser isogênica e determinar resultados mais homogêneos. Também, a inoculação dos animais com OROV pela via i.c. foi a escolhida porque matava todos os animais. 


\subsubsection{Scores clínicos}

Os sinais clínicos apresentados pelos camundongos infectados com OROV pela via i.c. foram avaliados durante todos os dias pós-infecção. Detectaram-se em $85 \%$ dos animais, sinais como imobilidade, pelo arrepiado, fotofobia, caminhada em círculos e sem equilibro, perda de peso, paralisia da pata. Até o dia 5 pós-infecção os animais manifestavam sinais graves como convulsões, espasmos, respiração rápida e finalmente morriam (tabela 4). Estas informações nos permitiram elaborar uma curva com scores clínicos, como mostra a figura 8 .

Tabela 4 - Score clinico dos camundongos inoculados pela via i.c com OROV.

\begin{tabular}{l|ll}
\hline 1 & Normal \\
\hline 2 & Imóvel, pelo arrepiado e fotofobia \\
\hline 3 & $\begin{array}{l}\text { Caminha em círculos sem equilibro, perdida } \\
\text { de peso, e paralisia da pata }\end{array}$ \\
\hline 4 & Convulsões e espasmos \\
\hline 5 & $\begin{array}{l}\text { Estado moribundo, olhos lagrimosos, } \\
\text { respiração rápida. }\end{array}$ \\
\hline
\end{tabular}

\section{Intracerebral}

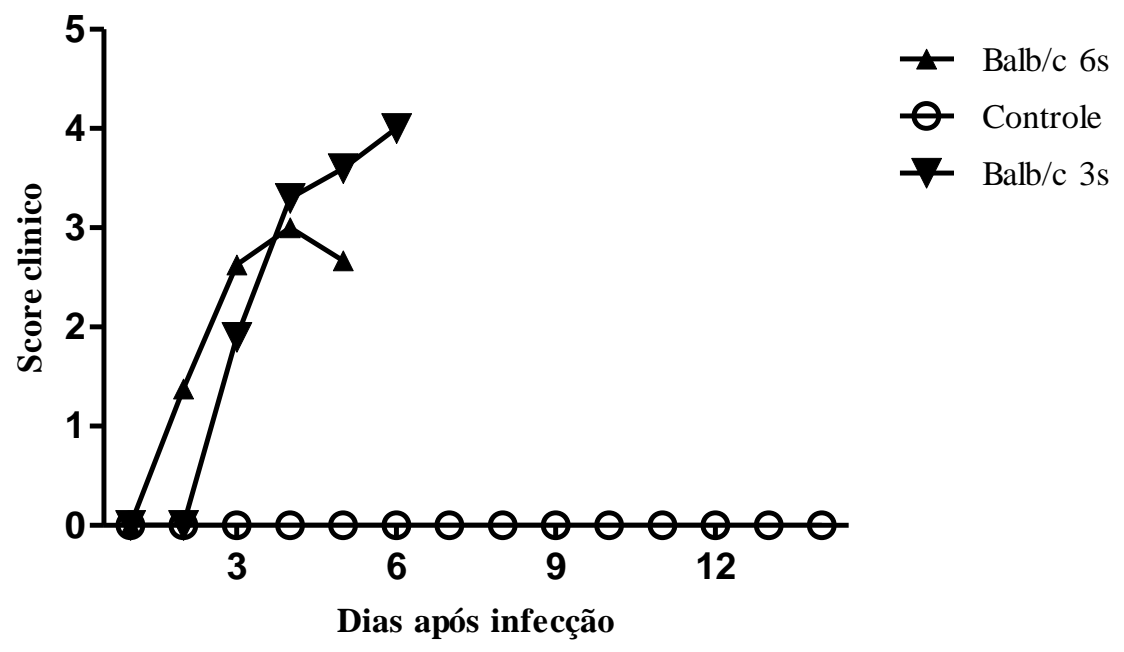

Figura 8. Score clínicos de camundongos Balb/C de 3 e 6 semanas de idade inoculados pela via intracerebral com OROV. 


\subsubsection{Dose Letal50 (LD50)}

A LD 50 observada nos camundongos Balb/c de 12 semanas foi $10^{5.4} \mathrm{em} 0.02 \mathrm{ml}$. Nos desafios dos animais utilizamos $10 \mathrm{LD}_{50}$ do OROV, visando a produzir morte em todos os animais não imunizados. Esta escolha baseou-se nos resultados de experimento mostrado na Figura 10, de gráfico.

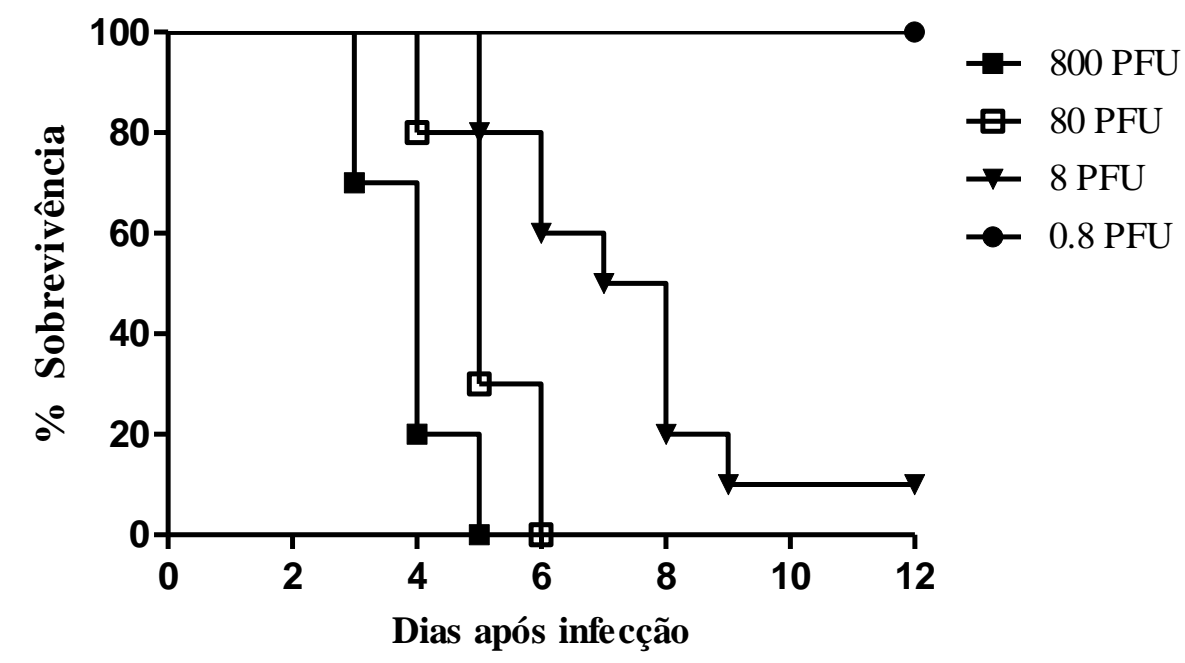

Figura 9. Representação gráfica da sobrevivência de grupos de camundongos Balb/C de 12 semanas de idade, inoculados por via intracerebral com diferentes diluições decimais do OROV de quantidades virais medidas em PFU.

\subsubsection{OROV nos órgãos de camundongos infectados via i.c.}

OROV mostrou-se detectável, praticamente, apenas em cérebro, nas primeiras 6 horas pós-infecção. Após 12horas o vírus pode ser encontrado em medula espinhal, fígado e baço com teores significativamente mais elevados em cérebro e medula espinhal. OROV não foi encontrado em soro, rim, pulmão e coração dos animais. Estes resultados são mostrados na Figura 10. 

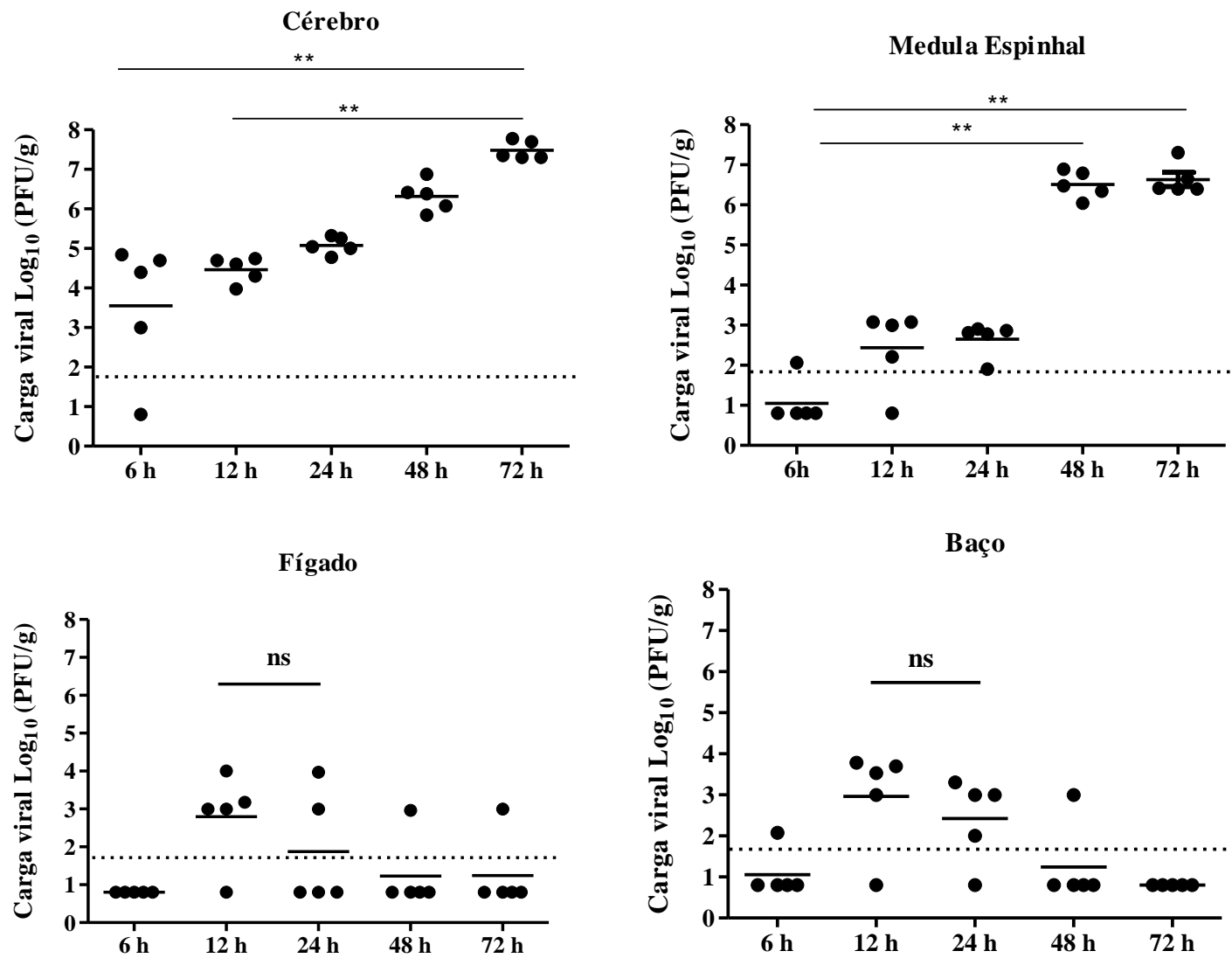

Soro

Rins
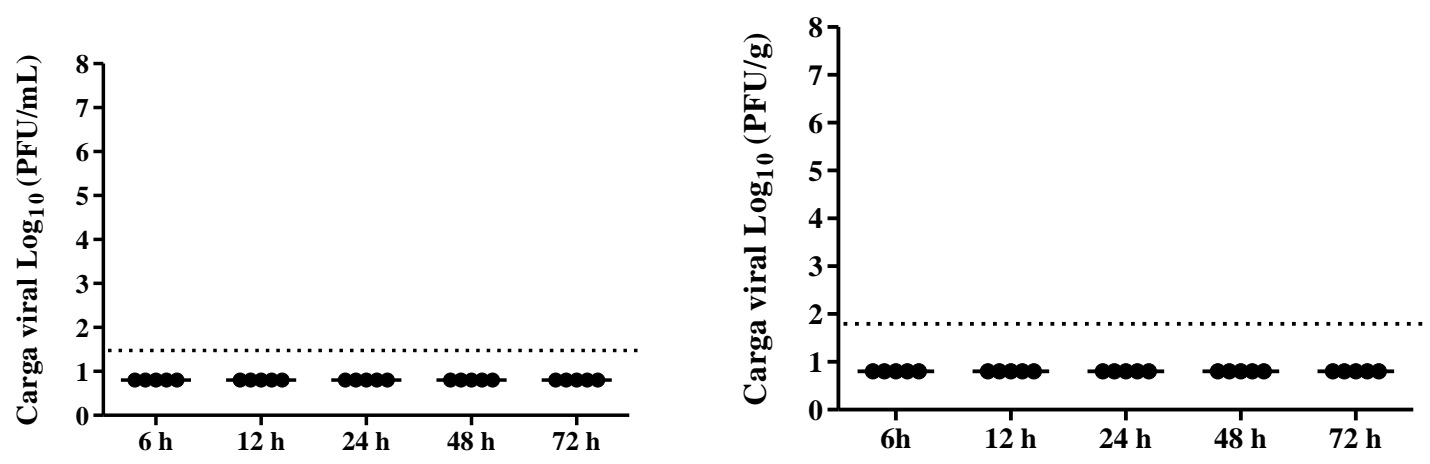

Pulmão

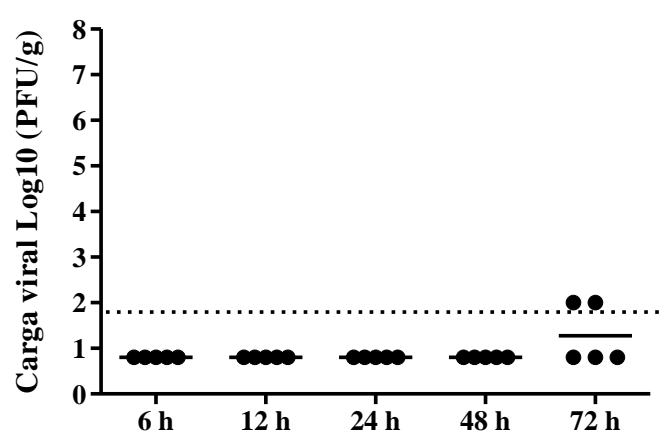

Coracão

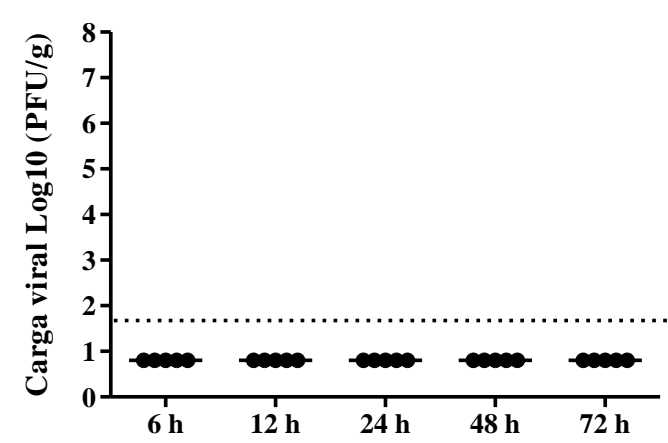


Figura 10. Carga de OROV em PFU/g de tecido, no cérebro, medula espinhal, fígado, baço, soro, rins, pulmão e coração dos camundongos infectados, segundo avaliações efetuadas 6, 12, 24 e 48 horas pósinfeção pela via intracerebral.

\subsection{Aplicação do modelo murino no estudo da resposta imune conferida pela NrOROV}

Os experimentos com o modelo murino de infecção por OROV visando ao estudo da resposta imune conferida pela NrOROV incluíram 6 grupos de 6 camundongos, que foram acompanhados por 62 dias e foram feitos como mostrado na Figura 11.

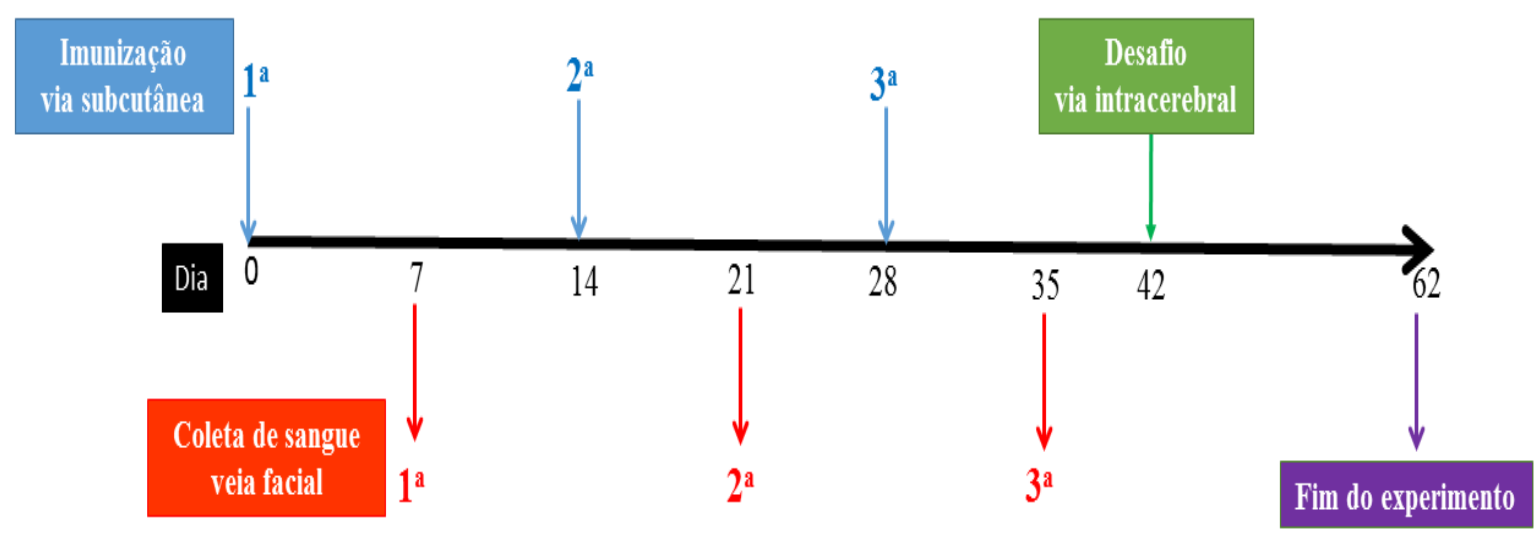

Figura 11. Protocolo de imunização com NrOROV e desafio dos 6 grupos de animais com OROV, incluindo controles positivo e negativo.

\subsubsection{Avaliação clínica e dos parâmetros hematológicos nos animais pós-imunizados}

Não se observaram mortes ou sinais clínicos de doença nos animais dos 6 grupos que receberam diferentes imunizações. Também, foram analisados parâmetros hematológicos que poderiam indicar distúrbios induzidos pelas formulações de imunização. Monitoraramse os camundongos imunizados quanto aos valores de hematócrito, contagens de plaquetas e leucócitos, incluindo neutrófilos e linfócitos. Conforme indicado na Tabela 5, não se observou alteração hematológica nos 6 grupos de camundongos imunizados com NrOROV ou OROV até 7 dias após a última imunização. 
Tabela 5 - Analises hematológico dos grupos de camundongos imunizados.

\begin{tabular}{lccccccc}
\hline $\begin{array}{c}\text { Parâmetros } \\
\text { Hematológicos }\end{array}$ & N & N+FCA & $\begin{array}{c}\text { N+Mont } \\
\text { +Poli }\end{array}$ & OROV & $\begin{array}{c}\text { OROV } \\
\text { +FCA }\end{array}$ & PBS & $\begin{array}{c}\text { Parâmetros } \\
\text { normais }\end{array}$ \\
\cline { 2 - 7 } & 1.3 & 2.6 & 2.3 & 1.1 & 0.96 & 1.7 & $1.0-5.5$ \\
\hline LEU $10 \% \mathrm{~mm}^{3}$ & 40 & 42 & 42 & 36 & 43 & 34 & $33.1-52.0$ \\
\hline HTO \% & 30 & 22 & 26 & 20 & 30 & 29 & $6-32$ \\
\hline NEU \% & 68 & 77 & 73 & 77 & 68 & 70 & $63-94$ \\
\hline LIN \% & 901 & 950 & 912 & 912 & 915 & 92 & $439-957$ \\
\hline PLT $10 \% / \mathrm{mm}^{3}$ & & & & & & 0 & \\
\hline
\end{tabular}

\subsubsection{Resposta humoral induzida pelas imunizações com antígeno NrOROV}

Os animais dos 6 grupos foram sangrados 7 dias pós-imunização por 3 vezes. EIA-ICC: Os soros foram analisados quanto à presença de anticorpos específicos de OROV por EIA-ICC. Dessa forma, foi possível detectar anticorpos após a $3^{\text {a }}$ imunização nos animais dos grupos N, N+FCA, N+Monta+Poli, OROV, OROV+FCA. Portanto, esses imunógenos foram eficazes na geração da resposta humoral. Observou-se que os grupos N+FCA e N+Mont+Poli, imunizados com NrOROV, apresentaram títulos de IgG > 5000, similares aos observados no grupo OROV+FCA, imunizado com o próprio OROV. (Figura 12). Verificou-se que o surgimento e a elevação dos títulos de anticorpos nos grupos $\mathrm{N}+\mathrm{FCA}$ e N+Mont+Poli, foi idêntica, elevando-se após a $2^{\mathrm{a}}$ imunização e com pico no $35^{\circ}$ dia pós- imunização. 


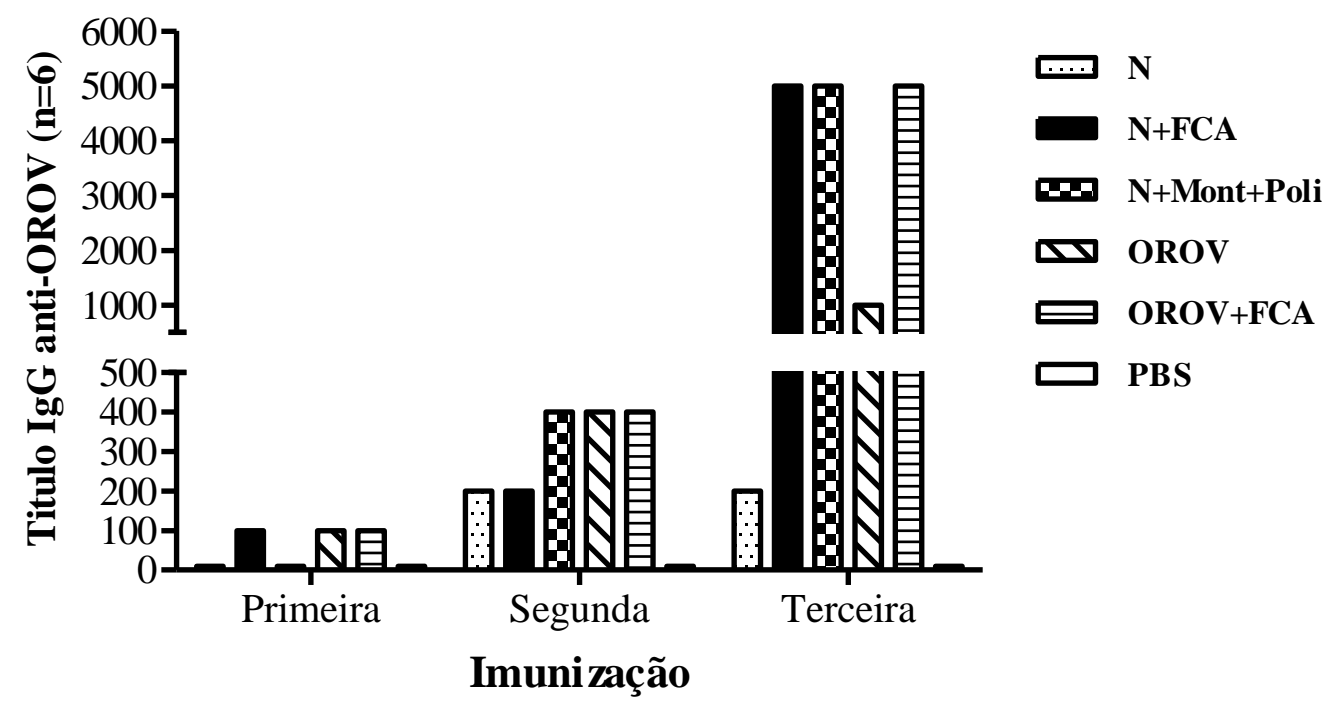

Figura 12. Títulos séricos de IgG contra OROV nos 6 grupos de camundongos utilizados nos experimentos de imunização com NrOROV. As análises foram feitas em duplicata e consideraram-se os valores das médias.

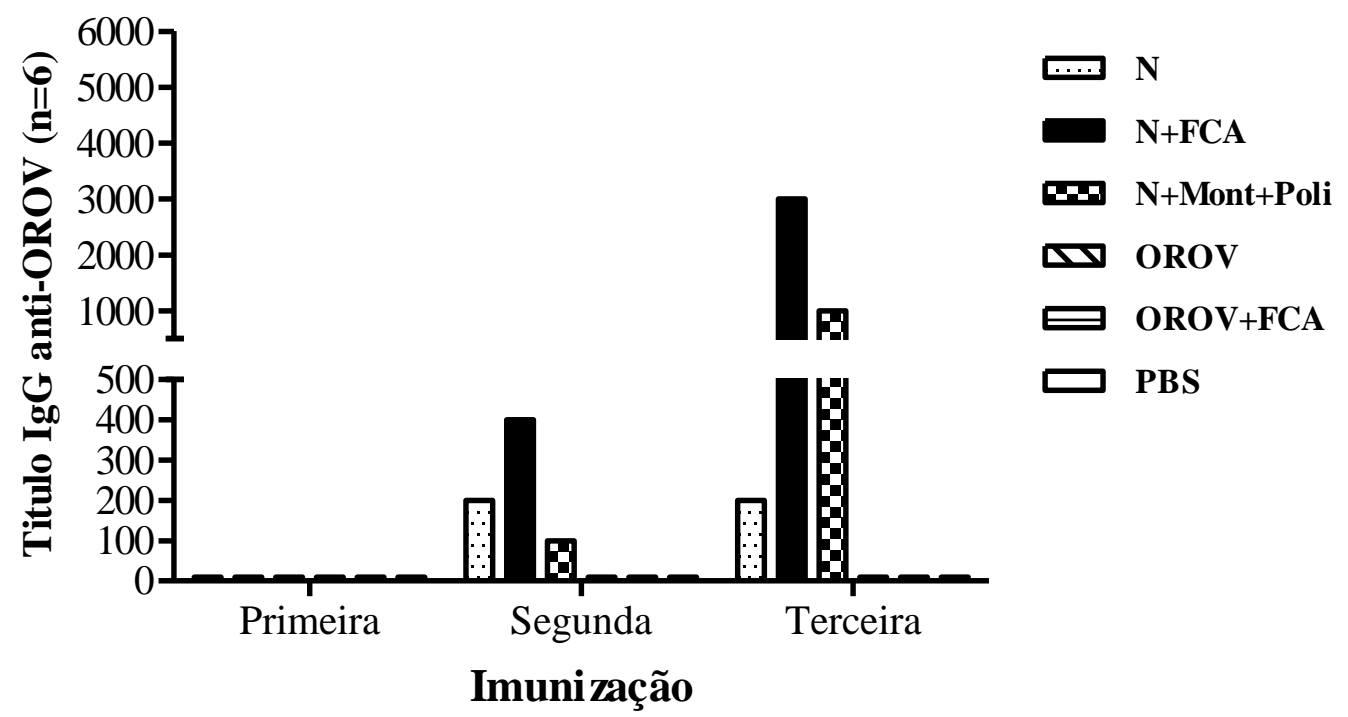

Figura 13. Títulos séricos de IgG contra NrOROV nos 6 grupos de camundongos utilizados nos experimentos de imunização com NrOROV. As análises foram feitas em duplicata e consideraram-se os valores das médias.

Teste de neutralização (PRNT): Os soros dos 6 grupos de animais que participaram dos experimentos de imunização com NrOROV foram testados quanto à produção de anticorpos neutralizantes contra OROV. Observou-se que os teores de anticorpos neutralizantes variaram grandemente nos grupos de animais, conforme o imunógeno. Os 
títulos PRNT nos grupos de camundongos que receberam NrOROV grupos N, N+FCA, $\mathrm{N}+$ Montanide+Poli, foram baixos e nos que receberam o próprio OROV, que foram elevados, com titulos de 2560 e 5120. Os resultados sugerem que NrOROV não possui capacidade de induzir anticorpos neutralizantes para OROV independente das preparações com adjuvantes utilizados. Estes resultados são mostrados na Figura 14.

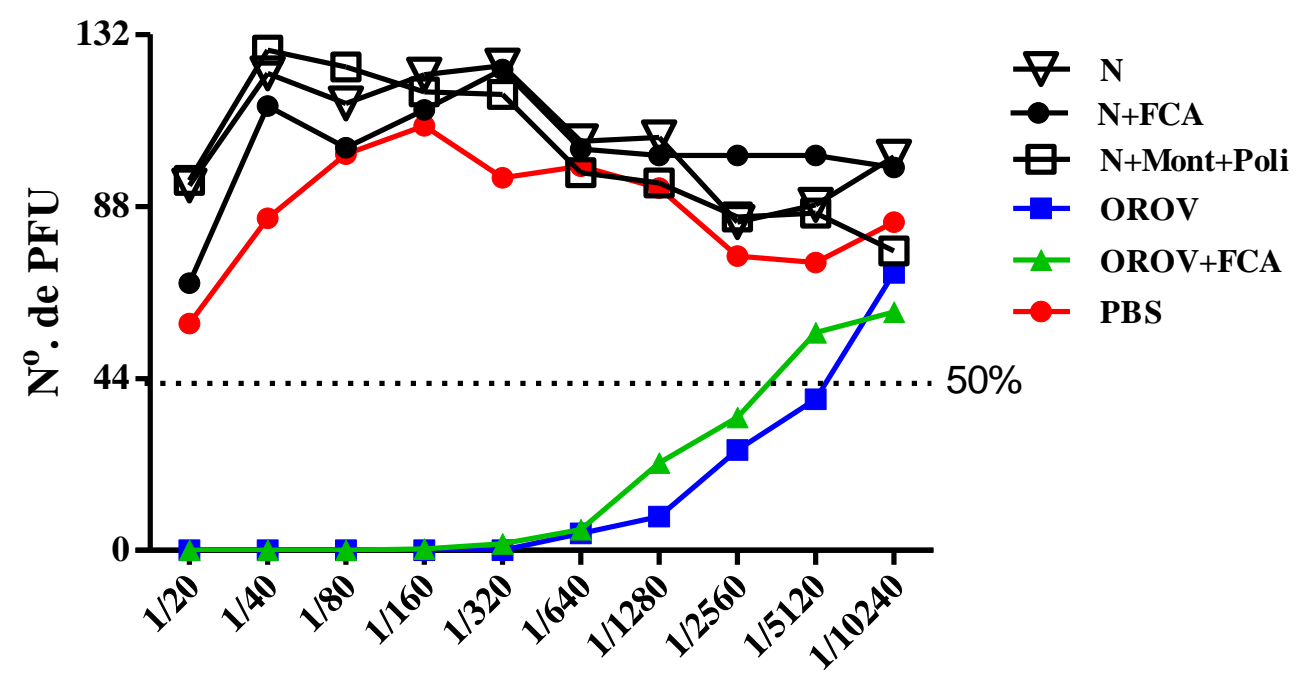

Diluição dos soros

Figura 14. Teores de anticorpos neutralizantes com base na redução de PFU. Dos soros dos 6 grupos de animais que participaram dos experimentos de imunização com NrOROV.

\subsubsection{Imunofluorescência Indireta (IFA) em microscópio confocal.}

Os soros dos 6 grupos de animais que participaram dos experimentos de imunização com NrOROV e OROV foram testados por IFA em microscopia confocal de células Hela infectadas com OROV. Observa-se pela análise das imagens na Figura 14, que as células infectadas com OROV mostram seus antígenos fluorescendo quando usado MIAF antiOROV (Figura B, D, E) e quando usado anticorpos anti-N (Figura G, H,). As imagens obtidas em reações com soros de animais que foram imunizados com $\mathrm{N}+\mathrm{FCA}$, sugerem que a proteína $\mathrm{N}$ se localize principalmente em região perinuclear, (Figura $\mathrm{I}, \mathrm{J}$ ), mas também em fábricas virais intracitoplasmáticas e região da membrana celular (Figura K, L) o que poderia ser outro estagio de infeção celular em que os vírus começam a sair da célula. Nota-se também que não apresenta fluorescência usando o soro de camundongos 
imunizados com PBS (figura $\mathrm{C}$ ) ou pouca fluorescência quando imunizado somente com NrOROV (Figura F); células não infectadas (Figura A) controle negativo.
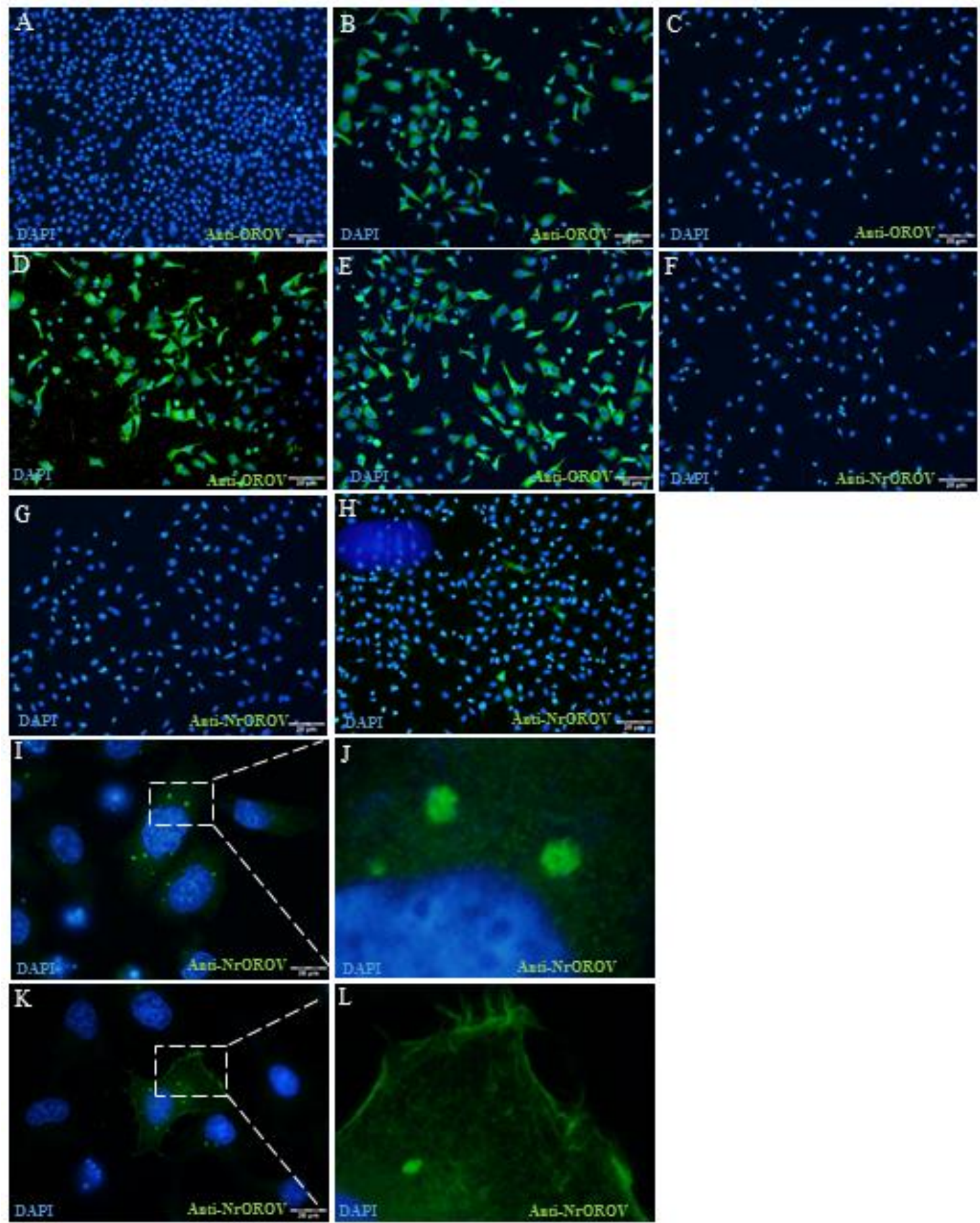
Figura 15. Fotografias de imunofluorescencia utilizando células HeLa infectadas com OROV para pesquisa de anticorpos anti-OROV em soro de camundongos. Microscopio confocal em aumento 40 x scala bar: 20 um; A: células não infectadas, B: células incubadas com MIAF (controle positivo); C: células incubadas com soro de camundongos imunizados com PBS; D: células incubadas com soro de camundongos imunizados com OROV; E: células incubadas com soro de camundongos imunizados com OROV+FCA; F: células incubadas com soro de camundongos imunizados com NrOROV; G: células incubadas soro de camundongos imunizados com NrOROV+Montanide+Poli I:C. H: células incubadas com soro de camundongos imunizados com NrOROV+FCA; I, K: aumento 100x scala bar: 20 um; I, L: aumento 1000x.

A distribuição temporal da proteína $\mathrm{N}$ ao longo da infecção foi acompanhada através de imunofluorescencia indireta, marcando o vírus com o soro de camundongo imunizado com NrOROV+FCA (anti-N). O padrão de marcação do vírus ao longo do ciclo replicativo esta demostrado na Figura 16. Pode-se observar que, em 1 h e 6 h p.i. (figura 16 A e B), a marcação viral se apresenta em pontos isolados dispersos no citoplasma, indicando que o vírus foi endocitado e possivelmente se encontra em endossomos. Em 12 h, 18 h e 24 h p.i (Figura 16 C, D, E), e possível observar que a marcação anti-N começa a adquirir um novo padrão. Há um aumento da intensidade da marcação, mantendo o padrão reticular; porém, em tais tempos, podemos observar a ocorrência de marcação anti-N concentrada em estruturas granulares dispersas no citoplasma, localizadas principalmente na região perinuclear e que aumentam em tamanho ao longo do tempo de infecção. Tais estruturas são maiores e mais evidentes a partir de $12 \mathrm{~h}$ p.i e provavelmente constituem as "fabricas" de produção viral nas células infectadas. O aparecimento dessas estruturas possivelmente indica que, após 6h de infecção, a célula já iniciou o processo de produção de novas partículas virais. Em 24 h p.i., (Figura 16 E), foi possível observar uma diminuição na intensidade da marcação das estruturas granulares e uma marcação anti-N na membrana celular, em 36 h p.i. (Figura 16 F), não se observou as estruturas granulares no citoplasma mas sim uma forte marcação na membrana celular. 

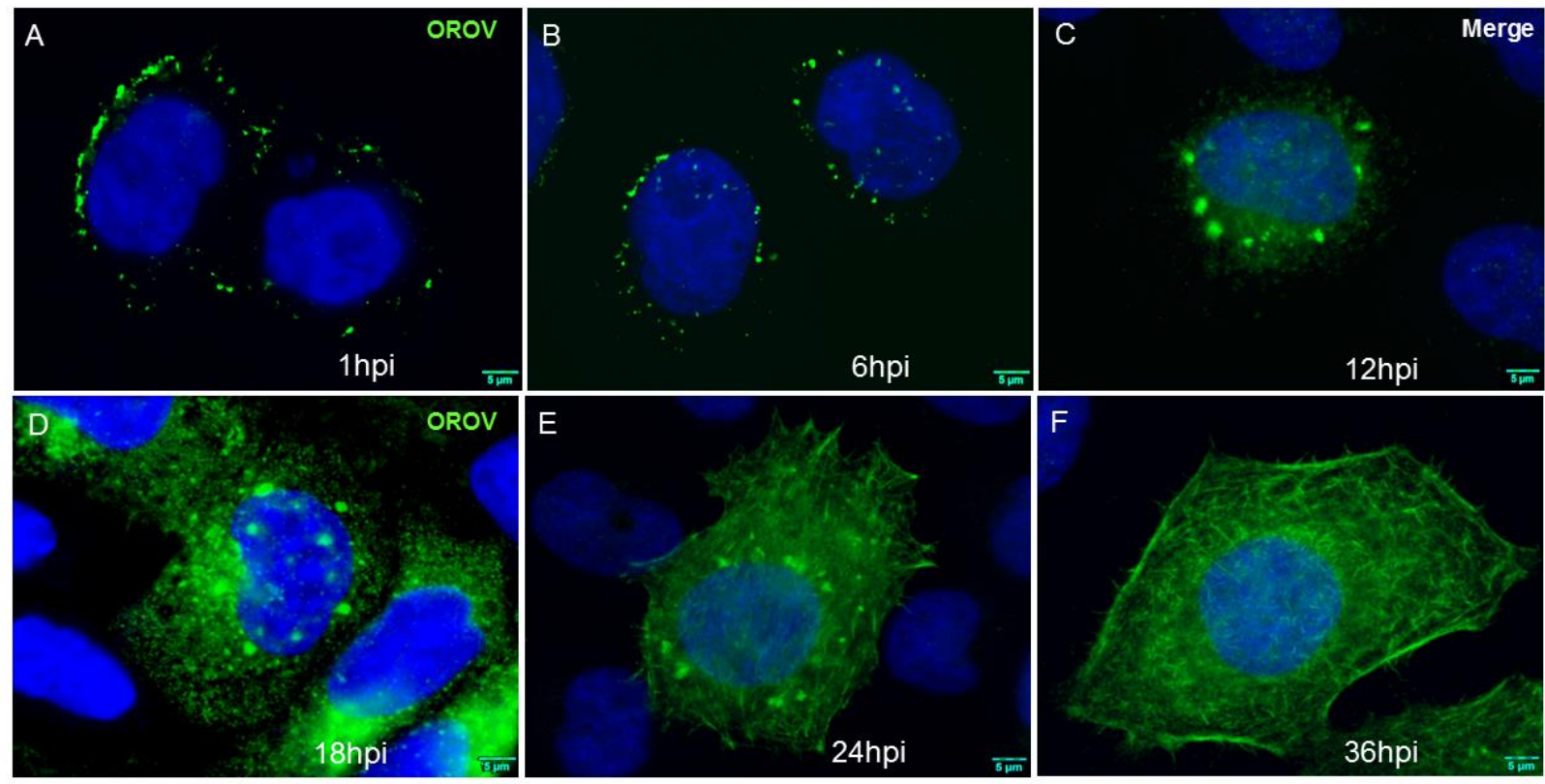

Figura 16. Células HeLa foram infectadas com OROV BeAn 19991 com um MOI de 1. Na 1, 6, 12, 18, 24 e 36 horas após infecção, células foram fixadas com paraformadehido e marcadas com Anti$\mathrm{N}$ e DAPI e analisadas em microscópio de fluorescência. Aumento 1000x. scala bar: 5 um.

\subsubsection{Sobrevida, peso e score clínico dos animais imunizados com $\mathrm{NrOROV}$, após desafio com OROV}

Os 6 grupos de camundongos, que receberam diferentes imunizações foram desafiados com $10 \mathrm{LD}_{50}$ de OROV pela via i.c. e os animais foram observados diariamente. Nos grupos de camundongos imunizados com $\mathrm{N}, \mathrm{N}+\mathrm{FCA}, \mathrm{N}+$ Mont+Poli, sobreviveram 80 a $85 \%$ mas esta diferença não foi estatisticamente significante quando comparada à sobrevida dos animais do grupo imunizados com PBS, que apresenta um $40 \%$ de sobrevivência. Portanto, a imunização com N reduziu em cerca de $40 \%$ a letalidade induzida em camundongos após desafio i.c. com OROV, embora sem significado estatístico. Os grupos imunizados com OROV, o controle positivo, mostraram $100 \%$ de sobrevida pós-desafio com o vírus (Figura 17). 

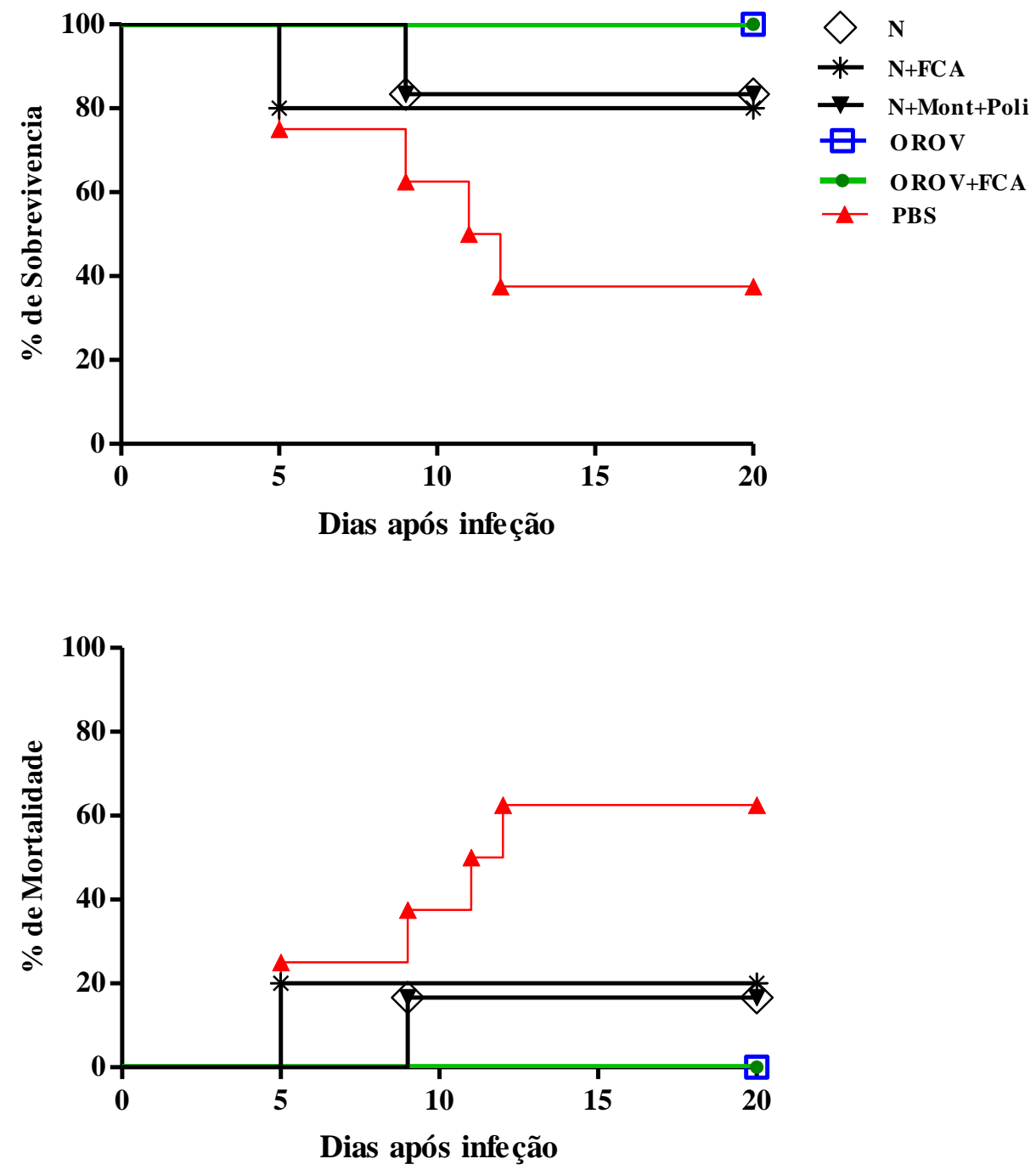

Figura 17. Porcentual de sobrevivência e mortalidade de camundongos imunizados.

Com relação ao peso dos 6 grupos de camundongos, que receberam diferentes imunizações e foram desafiados com OROV pela via i.c., observou-se que o grupo A imunizado somente com NrOROV, ganhou pouco peso em comparação aos animais dos grupos imunizados com NrOROV e adjuvantes, os quais apresentam maior ganancia de peso durante os dias após infecção. Os animais imunizados com OROV apresentam ganancia de peso, o grupo que foi imunizado apenas com PBS, apresenta uma perda de peso a partir dos 4 até 11 dias após infecção (Figura 17). 


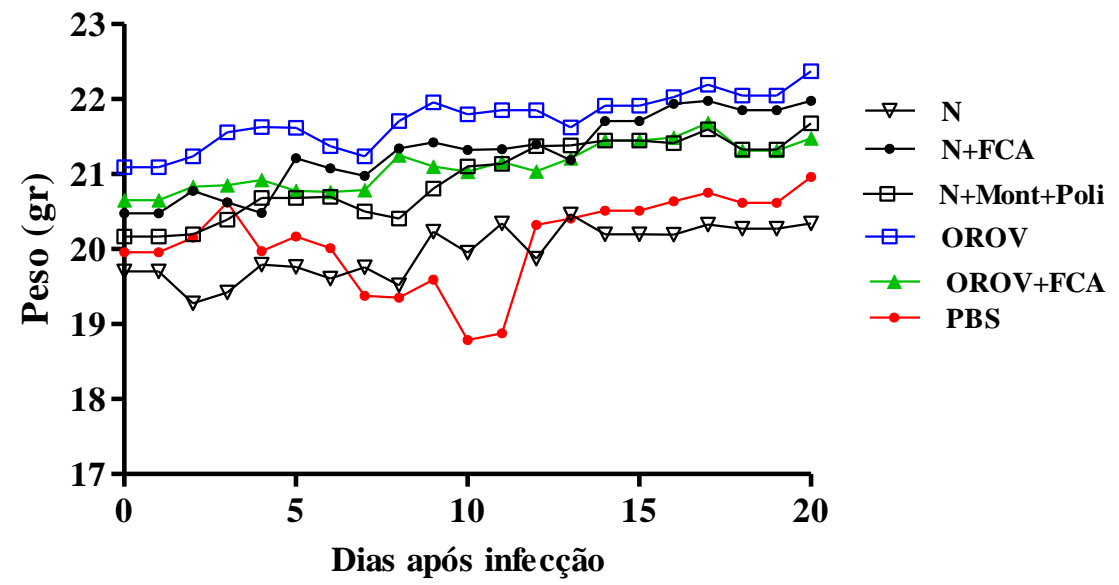

Figura 18. Evolução dos pesos dos camundongos dos 6 grupos, que receberam diferentes imunizações e foram desafiados com OROV pela via i.c.

Também, determinou-se o score clínico dos 6 grupos de camundongos, que receberam diferentes imunizações e foram desafiados com OROV pela via i.c., como mostra a Figura 18. Dos grupos imunizados com N, e N+Mont+Poli, apresentaram uma média de score clinico de 1 entre os dias 7 ao 9, após infecção, o grupo N+FCA apresenta uma média de score clinico de 1 entre os dias 4 ao 6 dia após infecção. Os grupos imunizados com OROV, apresentam uma média de score clinico de 0 durante toda a infecção. O grupo imunizado apenas com PBS tem uma média de score clinico de 1, nos dias 4 ao 12, após infecção.

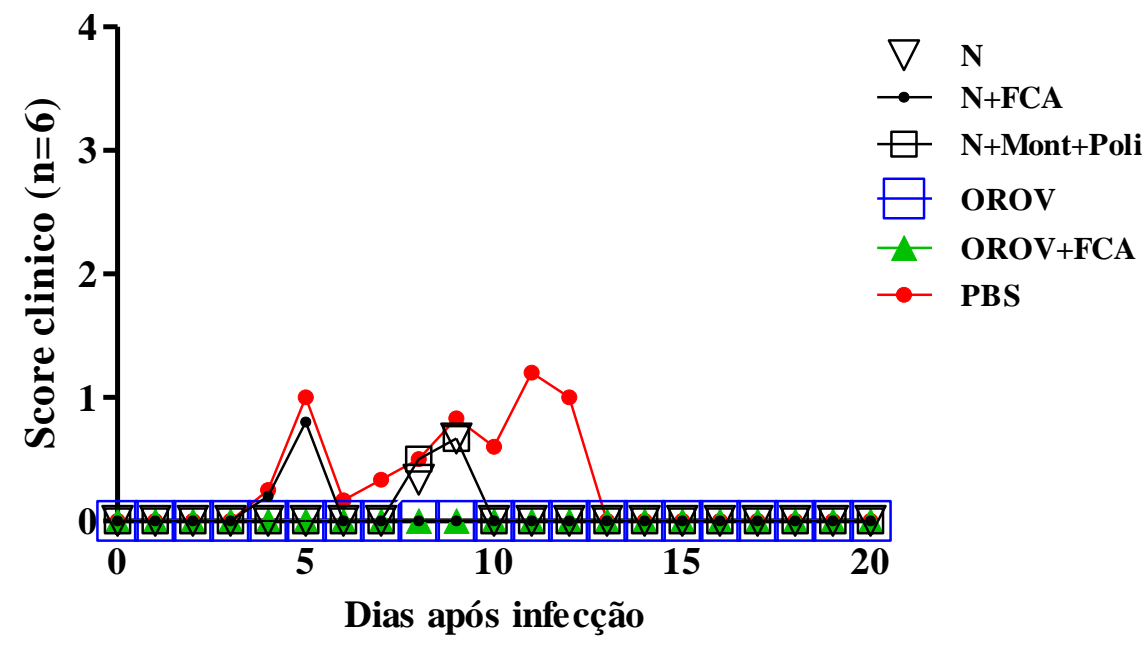

Figura 19. Score clínico dos grupos imunizados, que receberam diferentes imunizações e foram desafiados com OROV pela via i.c. 


\section{DISCUSSÃO}

O vírus Oropouche é um dos orthobunyavirus mais importantes associados a doenças humanas na américa tropical, com mais de 30 surtos importantes e meio milhão de casos relatados desde seu primeiro isolamento em 1955 (DA ROSA et al., 2017). Como mortes não foram registradas, pouco se sabe sobre a patogênese de infecções naturais de OROV. Também, a procura por estes vírus em indivíduos apresentando doença febril aguda e quadros neurológicos infecciosos, não é realizada na maioria dos casos. Porém, a dimensão deste agravo em saúde pública justifica, para prevenção e controle efetivo desta virose, o desenvolvimento de uma vacina. Entretanto, para avaliação preliminar da vacina, necessitaríamos de um modelo experimental da infecção por OROV, o que motivou grande parte do nosso trabalho. Por outro lado, o modelo experimental poderia, também, fornecer informações adicionais sobre a patogênese das infecções por OROV.

No presente estudo investigamos um modelo de infecção experimental da infecção pelo OROV visando a avaliar o papel imunogênico a proteína NrOROV. Para tanto, avaliamos múltiplos parâmetros: linhagens de camundongos Swiss e Balb/c, de 3 e 6 semanas, foram infectados com $3 \times 10^{6} \mathrm{PFU}$ de OROV, pela via intraperitoneal, intravenosa e subcutânea. Em todos estes experimentos, os animais exibiram sobrevida de 70 a 100\%, portanto, inadequada ao teste como vacina. Desta forma, ao final, passamos a testar a inoculação viral por via i.c. a qual mostrou-se capaz de matar todos os animais.

Também, escolhemos como mais adequado ao modelo experimental, camundongo da linhagem Balb/C que por ser isogênica permitiria obter resultados comparáveis. Modelos iniciais para dengue utilizaram injeções i.c. com altas doses de DENV neurovirulentas em camundongos recém-nascidos (SCHLESINGER, 1977). Em camundongos imunocompetentes adultos, a injeção viral i.c. induziu doença neurológica e paralisia, também, verificou-se que os camundongos inbred eram mais susceptíveis à infecção do DENV-2 que os outbred, indicando que a susceptibilidade pode depender dos fatores genéticos do hospedeiro (RAUT et al., 1996). O modelo de camundongo para a encefalite do Dengue tem sido amplamente utilizado para a avaliação de vacinas candidatas contra a Dengue (CLEMENTS et al., 2010; HERMIDA et al., 2004; LAZO et al., 2007; SIMMONS et al., 1998; SRIVASTAVA et al., 1995). Desta forma, a resposta imunitária 
protetora induzida por preparações de vacina é avaliada in vivo. No entanto, o modelo tem como desvantagem a via i.c. para o desafio viral, que é muito diferente da via natural de infecção (MARCOS et al., 2016).

Nos camundongos inoculados pela via i.c. com OROV, avaliamos a infecção do sistema nervoso. Os animais desenvolviam encefalite, com fotofobia, caminhada em círculos, perda de equilíbrio, e paralisia das patas trazeiras, além de sinais gerais, como pelos arrepiados e perda de peso. Três a 5 dias pós-infecção os animais tinham convulsões, espasmos e respiração rápida precedendo a morte por grave encefalite em todos os casos.

Em seres humanos, a infecção por OROV, após período de incubação 4 a 8 dias, produz doença febril de início brusco com febre calafrios, tonturas, cefaleia, dores musculares, artralgia e fotofobia (PINHEIRO et al., 1981b, 1982b; PINHEIRO F; TRAVASSOS DA ROSA; VASCONCELOS, 1997). A infecção por OROV produz viremia que é detectada apenas durante os primeiros dias de infecção. Fenômenos hemorrágicos (petequias, epistaxe e sangramento gengival) na doença por OROV foram relatados em um surto ocorrido em Manaus (MOURÃ̃̃̃ et al., 2009). O vírus encontra-se presente e se dissemina em leucócitos do sangue periférico (DE SOUZA LUNA et al., 2017). Embora a maioria dos pacientes se recupere dentro de 2 a 3 semanas sem seqüelas de longo prazo (PINHEIRO et al., 1981a), recidivas são comuns (PINHEIRO et al., 1981a). Em alguns pacientes, a infecção por OROV evolui para meningite e/ou encefalite (BASTOS et al., 2014; BASTOS MDE et al., 2012; PINHEIRO et al., 1982b). De fato, o OROV foi detectado no líquido cefalorraquidiano em quase $7 \%$ dos pacientes com meningoencefalite suspeita de ter uma infecção viral aguda do sistema nervoso central (SNC) em algumas situações (BASTOS et al., 2014; BASTOS MDE et al., 2012). Os sinais e sintomas neurológicos em pacientes com febre OROV incluem vertigem, letargia, diplopia, nistagmo e rigidez nucal (PINHEIRO et al., 1981a,. 1982b). Em modelo hamster de infecção por OROV usando inoculação subcutânea, o período de incubação foi de 3 a 9 dias e mais de 50\% dos animais desenvolveram letargia, eriçamento dos pelos, tremores, paralisia. Destes, aproximadamente um terço morreram (RODRIGUES et al., 2011). Camundongos BALB/c recém-nascidos inoculados com OROV por via subcutânea costumam adoecer 5 dias pós-infecção apresentando letargia, paralisia e 85\% dos animais evoluindo para a morte em até 10 dias (SANTOS et al., 2012). 
Escolhemos utilizar inóculo contendo $8 \times 10^{5}$ PFU de OROV na infeçção i.c. dos camundongos, capaz de matar todos os animais. Nas primeiras 6 horas pós-infecção o vírus foi detectável apenas no cérebro. Após 12horas, o vírus já havia se espalhado pelo organismo dos animais sendo encontrado em medula espinhal, fígado e baço, com teores significativamente mais elevados em cérebro e medula espinhal. Entretanto, reconhecemos que utilizando uma via de infecção completamente artificial e direta, no sistema nervoso central (SNC), a disseminação viral não pode ser adequadamente avaliada naquele local. Porém observamos que o espalhamento do OROV pelo SNC causa danos neurológicos graves, incluindo paralisia dos membros posteriores, caminhada em círculos com perda de equilíbrio, convulsões e espasmos. Ainda, evidenciamos altos títulos virais em cérebro e medula espinhal. Nossos resultados são comparáveis aos de Rodrigues e colaboradores (2011), com o modelo em hamster, onde a invasão do SNC pelo OROV produziu danos neurológicos graves com deficiências motoras, paralisia dos membros posteriores, marcha circular unidirecional contínua e ainda, presença evidente de antígenos virais na maioria das regiões do cérebro (RODRIGUES et al., 2011). Também, Santos e colaboradores (2014), observaram o neurotropismo de OROV por imunohistoquímica determinando que a infecção avança das partes posteriores do cérebro, incluindo a substância cinzenta periaquedutal, em direção ao prosencéfalo (SANTOS et al., 2014). Em camundongos $\mathrm{BALB} / \mathrm{c}$ recém-nascidos inoculados via subcutânea com OROV, à imunohistoquímica, observou-se que neurônios foram células alvo importantes da infecção por OROV. A histopatológia revelou reação glial e ativação de astrócitos no cérebro e medula espinhal, com apoptose neuronal. (SANTOS et al., 2012).

Nosso modelo experimental murino mostrou que OROV, além do cérebro, local do inóculo, se dissemina provavelmente por via hematogênica infectando outros órgãos, particularmente fígado e baço. Estes achados corroboram os de trabalho pioneiro de Araujo, em 1978, descrevendo OROV em lesões hepáticas nos hamsters, com necrose significativa de hepatócitos e hipertrofia considerável de células de Kupffer 6 horas pósinfecção i.c., sugerindo uma disseminação hematogênica do vírus a partir do cérebro e atingindo o fígado. Rodrigues e colaboradores (2011) inocularam hamsters com OROV pela via subcutânea e observaram altos títulos virais no sangue, fígado e cérebro, mas não nos outros órgãos. Exames histopatológicos revelaram meningoencefalite e hepatite, com 
abundante antígeno de OROV em fígado e cérebro. A imunocoloração difusa de galectina-3 no cérebro e fígado mostrou ativação das células microgliais e de Kupfer. Estes resultados de Rodrigues, utilizando outra via de inoculação, mais próxima da via natural de infecção, também, corrobora os resultados de Araujo, mostrando que, independente da via de inoculação, cerebral ou subcutânea, OROV produz infecção disseminada com hepatite grave, em hamster.

A proteína $\mathrm{N}$ dos Orthobunyavirus, envolve e protege o genoma viral. Também, facilita a formação da estrutura panhandle do RNA viral, com papel importante na replicação. A proteína $\mathrm{N}$ é o mais abundante produto encontrado em virions e em células infectadas (FIELDS; HOWLEY; KNIPE, 2007; MIR; PANGANIBAN, 2006) e também, é o principal antígeno dos Orthobunyavírus, sendo capaz de estimular uma resposta humoral vigorosa, com produção de altos níveis de anticorpos IgG e IgM específicos (ELLIOTT, 2014; LEONARD et al., 2005; OSBORNE; ELLIOTT, 2000; SCHWARZ et al., 1996; ZOLLER et al., 1993). Portanto, pareceu-nos que estudar a imunogenicidade conferida pela proteína $\mathrm{N}$ do OROV, além de avaliar sua capacidade para bloquear a infecção viral, poderia adquirir grande importância no futuro desenvolvimento de uma vacina. Para tanto, dispusemos da proteína $\mathrm{N}$ recombinante do OROV (NrOROV) produzida com sucesso por nosso grupo, em 2002, inicialmente para uso como antígeno em um ensaio imunoenzimático de diagnóstico sorológico da virose. Para tanto, o gene de $\mathrm{N}$ foi clonado em Escherichia coli cepa BL21 que respondeu à indução com IPTG produzindo a proteína, o que foi confirmado por eletroforese em SDS-Page e finalmente, a proteína foi purificada em colunas de cromatografia por afinidade (AQUINO, 2002).

Uma vez confirmado e quantificado nosso estoque da NrOROV, passamos aos estudos sobre imunogenicidade e capacidade de induzir proteção contra as infecções pelo OROV no modelo experimental em camundongos. Consideramos importante nos estudos com imunização de animais, que a formulação da vacina fosse adaptada para oferecer eficácia e segurança. Para tanto, adjuvantes foram adicionados ao antígeno. Os camundongos foram imunizados com NrOROV e FCA, NrOROV e Montanide Poli I:C. Os anticorpos séricos produzidos pelos animais imunizados com mistura antígenoadjuvante foram testadas por EIA-ICC exibindo altos títulos de IgG, similar aos do grupo controle imunizado com OROV e FCA. Quando testados por ELISA com antígeno 
NrOROV, os animais exibiram títulos menores. Todas as formulações, com diferentes adjuvantes, induziram forte resposta humoral. Porém, estes anticorpos não mostraram capacidade neutralizante no PRNT.

Padronizamos nosso modelo experimental em camundongos Balb/c de 12 semanas de idade, inoculados i.c com $8 \times 10^{5}$ PFU de OROV, que foi capaz de induzir $100 \%$ de letalidade após o terceiro dia da infecção. Também, avaliamos parâmetros clínicos (scores clínicos) da doença nos animais infectados. Estes scores clínicos foram comparados aos observados nos animais imunizados com NrOROV e adjuvantes. Observamos que estes animais começaram a ganhar peso a partir do 5 dia p.i., diferentemente dos animais no grupo imunizado somente com $\mathrm{NrOROV}$ que só ganhou peso a partir do $9^{\circ}$ dia p.i. e como esperado, diferente dos animais imunizados com PBS, que perderam peso a partir do $3^{\circ}$ dia p.i. No grupo de animais imunizados com NrOROV e FCA observou-se score clínico de 1, entre o 4 e 6 dia p.i. e nos grupos imunizados com NrOROV somente ou com Montanide e Poli I:C score clinico de 1 ocorria entre 8 e 10 dias p.i. O grupo de animais imunizado com PBS exibia o maior score clínico do $4^{\circ}$ ao $13^{\circ}$ dia p.i. e o grupo de animais imunizados com OROV não apresentou sinal de doença. Portanto, nossos resultados sugerem que a imunização de NrOROV com adjuvantes determina doença por OROV de menor gravidade ou retarde esta nos animais.

Os anticorpos produzidos pelos camundongos imunizados com as diferentes formulações de NrOROV reagiram fortemente com OROV nos ensaios EIA-ICC e também, por imunofluorescência indireta. Células HeLa infectadas com OROV exibiram antígenos fluorescentes ao reagirem com anticorpos dos camundongos imunizados com NrOROV e adjuvantes (Montanide mais Poli I:C, NrOROV e FCA), como mostram as Figuras $15 \mathrm{G}$ e $\mathrm{H}$. As imagens mostram a proteína $\mathrm{N}$ principalmente na região perinuclear (Figura $15 \mathrm{I}, \mathrm{J}$ ) e na membrana celular (Figura $15 \mathrm{~K}, \mathrm{~L}$ ) sugerindo estágio mais precoce e outro mais tardio da infeção celular. Para entender a distribuição temporal da proteína $\mathrm{N}$ ao longo da infecção celular realizamos imunofluorescência na qual utilizamos soro de camundongo imunizado com NrOROV e FCA. Isto permitiu observar o ciclo replicativo viral, como mostra a Figura 16. Observamos que 1 h e 6 h p.i. (Figura 16 A e B) a marcação viral se apresenta em pontos isolados dispersos no citoplasma, indicando que o vírus foi endocitado e possivelmente se encontra em endossomos; 12 h, 18 h e 24 h p.i. 
(Figura 16 C, D e E) a marcação anti-N aumenta sua intensidade com padrão reticular nas estruturas granulares localizadas principalmente em região perinuclear aumentando em tamanho com o tempo de infecção. Tais estruturas, observadas $12 \mathrm{~h}$ p.i., sugerem fábricas de produção viral. Portanto, o aparecimento das fábricas $6 \mathrm{~h}$ p.i., possivelmente, indica que a célula já tenha iniciado o processo de produção das novas partículas virais; com 24 h p.i. (Figura 16 E), foi possível observar diminuição na marcação das estruturas granulares e o surgimento de marcação em membrana celular; finalmente, com 36 h p.i. (Figura 16 F), observa-se apenas uma forte marcação na membrana celular.

Nossos resultados corroboram os de estudo realizado por Mendonça (2014), também caracterizando o ciclo replicativo de OROV em células HeLa e observando o vírus em endossomos iniciais e tardios nas primeiras horas de infecção. Até 2 h p.i., o vírus apresentou marcação em pontos dispersos pelo citoplasma, sugerindo localização em endossomos. Marcando a proteína endossomal HRS, os autores confirmaram que OROV estava presente em endossomos iniciais $1 \mathrm{~h}$ p.i. e posteriormente em endossomos tardios, marcados com CD63-GFP. O vírus em endossomos tardios depende de acidificação para ter seu genoma liberado no citoplasma (SANTOS et al., 2008). A partir de 3 h p.i., a marcação para OROV apresentou um padrão reticular, disperso no citoplasma e colocalizando com marcadores de retículo endoplasmático, a proteína solúvel YFP-KDEL e a proteína integral de membrana calnexina. Entre 5 e 24 h p.i., observaram-se estruturas grânulares citoplasmáticas de aproximadamente $2.5 \mu \mathrm{m}$ de diâmetro, envoltas por membrana e contendo calnexina, provavelmente, fábricas virais. Utilizando Western blot, observou-se que $\mathrm{N}$ era a principal proteína detectada pelo anticorpo utilizado neste estudo (MENDONÇA, 2014).

Também, em outros estudos, padrões de marcação semelhantes a esse foram observados para a proteína $\mathrm{N}$ de flebovirus, hantavírus e vírus Tomato spottes wilt (TSWV, gênero Tospovius) (KATZ et al., 2010; RAMANATHAN et al., 2007; SNIPPE et al., 2007). Embora os autores não tenham entrado em detalhes quanto ao significado do padrão de distribuição da proteína $\mathrm{N}$, é possível que as estruturas grânulares descritas consistam nas fabricas virais desses vírus. Snippe e colaboradores (2007) observaram que a expressão da proteína N do TSWV em células BHK-21 confere um padrão de marcação perinuclear; porém, quando realizada a co-expressão da proteína N com as glicoproteínas Gc e Gn 
virais, a marcação adquiriu padrão granular disperso pelo citoplasma, semelhante ao observado em nosso estudo e no trabalho de Mendonça (2014). Considerando esses dados, a formação das fabricas virais observada 12 h p.i., nas células infectadas por OROV deve estar relacionada ao início da tradução das glicoproteínas virais, com deslocamento da proteína N para essas estruturas.

Mesmo sem ter induzido anticorpos neutralizantes, a imunização dos camundongos com NrOROV e adjuvantes induziu proteção contra o desafio por $10 \mathrm{LD}_{50}$ de OROV pela via i.c. Elevou-se a proporção de sobreviventes em $40 \%$ entre os imunizados com essa preparação quando comparada ao grupo controle. Entretanto, isto não foi estatisticamente significante. Tal fato poderia estar relacionado `a baixa capacidade em induzir anticorpos neutralizantes previamente comentada.

São curiosos os achados em estudo prévio com vacina para OROV. Utilizando hamsters recém-nascidos imunizados via s.c., com OROV inativado por luz UV, observouse proteção dos animais, porém, sem induzir anticorpos detectáveis e sem reduzir a carga viral em órgãos. OROV inativado por tratamento químico com detergente e fixado com paraformadehido, foi usado seqüencialmente, induzindo proteção parcial dos animais desafiados com OROV neurovirulento, porém sem induzir anticorpos detectáveis e sem reduzir carga viral em órgãos. Por outro lado, OROV atenuado por passagens seriadas em culturas celulares induziu soroconversão em hamsters com produção de anticorpos neutralizantes. (RODRIGUES, 2012).

Consideramos como limitação de nosso estudo não termos conseguido avaliar a imunidade celular nos animais imunizados com NrOROV. Inclusive, porque mesmo sem anticorpos neutralizantes, isto poderia explicar a relativa proteção pós-desafio com OROV, apresentada por alguns grupos de camundongos.

Em resumo, acreditamos que este estudo tenha contribuído para o conhecimento sobre o vírus Oropouche por ter propiciado um modelo experimental em camundongos que mostrou a capacidade de disseminação própria deste vírus. Nosso modelo experimental não evidenciou a utilidade da proteína $\mathrm{N}$ recombinante do vírus Oropouche como vacina pois não induziu anticorpos neutralizantes e não reduziu significantemente a letalidade pósdesafio. Por outro lado, os anticorpos produzidos pelos animais imunizados permitiram estudar o ciclo de replicação celular do OROV utilizando imunofluorescência. 


\section{CONCLUSÕES}

- Camundongos Balb/c de 6 a 12 semanas infectados com OROV pela via intracerebral desenvolvem doença a partir do $3^{\circ}$ dia após a infecção com $100 \%$ de letalidade.

- Em camundongos Balb/c de 12 semanas infectados pela via intracerebral, OROV é encontrado em medula espinhal, fígado e baço 12 horas após a infecção.

- Soro de camundongos imunizados com NrOROV e adjuvantes, quando testados pelo EIA-ICC contra o vírus infectando células, apresentam altos títulos de IgG mas, quando testados por ELISA contra NrOROV, seu imunógeno original, apresentam títulos mais baixos

- O soro de camundongos imunizados com NrOROV e FCA permitiu estudar a montagem e a eliminação da progênie viral em células HeLa infectadas com OROV.

- Camundongos imunizados com NrOROV e adjuvantes não produzem anticorpos neutralizantes para OROV.

- A imunização com a proteína NrOROV, mesmo combinada a adjuvantes, induziu proteção não significante nos camundongos desafiados com OROV. 


\section{REFERÊNCIAS BIBLIOGRÁFICAS}

ACRANI, G. O. et al. Apoptosis induced by Oropouche virus infection in HeLa cells is dependent on virus protein expression. Virus Res, v. 149, n. 1, p. 56-63, 2010.

ACRANI, G. O. et al. Establishment of a minigenome system for Oropouche virus reveals the $\mathrm{S}$ genome segment to be significantly longer than reported previously. J Gen Virol, v. 96, n. Pt 3, p. 513-523, 2015.

ANDERSON, C. R. et al. Oropouche virus: a new human disease agent from Trinidad, West Indies. Am J Trop Med Hyg, v. 10, p. 574-578, 1961.

AQUINO, V. H. Seqüenciamento nucleotídico completo e estudos associados ao genoma do Bunyavirus Oropouche. [s.1.] São Paulo, 2002.

AQUINO, V. H.; FIGUEIREDO, L. T. Linear amplification followed by single primer polymerase chain reaction to amplify unknown DNA fragments: complete nucleotide sequence of Oropouche virus M RNA segment. J Virol Methods, v. 115, n. 1, p. 51-57, 2004.

ARAUJO, R. et al. [Ultrastructural changes in the hamster liver after experimental inoculation with Oropouche arbovirus (type BeAn 19991)]. Rev Inst Med Trop Sao Paulo, v. 20, n. 1, p. 45-54, 1978.

AZEVEDO, R. DO S. DA S. et al. Reemergence of Oropouche Fever, Northern Brazil. Emerging Infectious Diseases, v. 13, n. 6, p. 912-915, jun. 2007.

BAISLEY, K. J. et al. Epidemiology of endemic Oropouche virus transmission in upper Amazonian Peru. Am J Trop Med Hyg, v. 59, n. 5, p. 710-716, 1998.

BASTOS, M. S. et al. Detection of Herpesvirus, Enterovirus, and Arbovirus infection in patients with suspected central nervous system viral infection in the Western Brazilian Amazon. J Med Virol, v. 86, n. 9, p. 1522-1527, 2014.

BASTOS MDE, S. et al. Identification of Oropouche Orthobunyavirus in the cerebrospinal fluid of three patients in the Amazonas, Brazil. Am J Trop Med Hyg, v. 86, n. 4, p. $732-$ 
$735,2012$.

CARDOSO, B. F. et al. Detection of Oropouche virus segment $\mathrm{S}$ in patients and inCulex quinquefasciatus in the state of Mato Grosso, Brazil. Mem Inst Oswaldo Cruz, v. 110, n. 6, p. 745-754, 2015.

CHAVEZ, R.; COLAN, E.; PHILLIPS, I. Fiebre de Oropuche en Iquitos: reporte preliminar de 5 casos. Rev Farmacol Terap 1, p. 12-14, 1992.

CLEMENTS, D. E. et al. Development of a recombinant tetravalent dengue virus vaccine: Immunogenicity and efficacy studies in mice and monkeys. Vaccine, v. 28, n. 15, p. 2705$2715,2010$.

DA ROSA, J. F. T. et al. Oropouche Virus: Clinical, Epidemiological, and Molecular Aspects of a Neglected Orthobunyavirus. The American Journal of Tropical Medicine and Hygiene, p. 16-0672, 6 fev. 2017.

DE SOUZA LUNA, L. K. et al. Oropouche virus is detected in peripheral blood leukocytes from patients. Journal of medical virology, v. 89, n. 6, p. 1108-1111, jun. 2017.

DIETZGEN, R. et al. In: Virus Taxonomy: Ninth Report of the International Committee on Taxonomy of Viruses. p. 193-213, 2012.

ELLIOTT, R. M. Orthobunyaviruses: recent genetic and structural insights. Nat Rev Microbiol, v. 12, n. 10, p. 673-685, 2014.

FREITAS, R. B. et al. Epidemia de virus Oropouche no leste do Para, 1979. International Symposium on Tropical Arboviroses and Hemorrhagic Fever., p. 59-71, 1982.

HERMIDA, L. et al. A dengue-2 Envelope fragment inserted within the structure of the P64k meningococcal protein carrier enables a functional immune response against the virus in mice. Journal of virological methods, v. 115, n. 1, p. 41-9, jan. 2004.

$\mathrm{HOCH}$, A. L. et al. Laboratory transmission of Oropouche virus by Culex Quinquefasciatus Say. Bull Pan Am Health Organ, v. 21, n. 1, p. 55-61, 1987.

KATZ, A. et al. Oligomerization of Uukuniemi virus nucleocapsid protein. Virology 
journal, v. 7, p. 187, 10 ago. 2010.

LAZO, L. et al. A recombinant capsid protein from Dengue-2 induces protection in mice against homologous virus. Vaccine, v. 25, n. 6, p. 1064-1070, 2007.

LENNETE, E.; SCHMIDT, N. (EDS.). Arboviruses. In: Diagnostic Procedures for viral, Rickettsial and Chlamydial Infections. Fifth ed. Washigton, DC.: [s.n.]. p. 1138.

MARCOS, E. et al. Dengue encephalitis-associated immunopathology in the mouse model: Implications for vaccine developers and antigens inducer of cellular immune response. Immunology Letters, v. 176, p. 51-56, 2016.

MENDOÇA, L. R. Caracterização de ciclo replicativo de virus Oropouche em células HeLa. [s.1.] Universidade de São Paulo, 2014.

MORELI, M. L. et al. Diagnosis of Oropouche virus infection by RT-nested-PCR. J Med Virol, v. 66, n. 1, p. 139-142, 2002.

MOURÃÃO, M. P. G. et al. Oropouche fever outbreak, Manaus, Brazil, 2007-2008. Emerging infectious diseases, v. 15, n. 12, p. 2063-4, dez. 2009.

MURPHY, F. A.; HARRISON, A. K.; WHITFIELD, S. G. Bunyaviridae: morphologic and morphogenetic similarities of Bunyamwera serologic supergroup viruses and several other arthropod-borne viruses. Intervirology, v. 1, n. 4, p. 297-316, 1973.

NUNES, M. R. et al. Oropouche virus isolation, southeast Brazil. Emerg Infect Dis, v. 11, n. 10, p. 1610-1613, 2005.

PINHEIRO, F. et al. Epidemia de virus Oropouche em Belem. Revista do Serviço Especial de Sauìde Puìblica 12, p. 13-23, 1962.

PINHEIRO, F. P. et al. An outbreak of Oropouche virus diease in the vicinity of santarem, para, barzil. Tropenmed Parasitol, v. 27, n. 2, p. 213-223, 1976.

PINHEIRO, F. P. et al. Oropouche virus. I. A review of clinical, epidemiological, and ecological findings. Am J Trop Med Hyg, v. 30, n. 1, p. 149-160, 1981a. 
PINHEIRO, F. P. et al. Oropouche virus. IV. Laboratory transmission by Culicoides paraensis. Am J Trop Med Hyg, v. 30, n. 1, p. 172-176, 1981 b.

PINHEIRO, F. P. et al. Transmission of Oropouche virus from man to hamster by the midge Culicoides paraensis. Science, v. 215, n. 4537, p. 1251-1253, 1982a.

PINHEIRO, F. P. et al. [Meningitis associated with Oropouche virus infections]. Rev Inst Med Trop Sao Paulo, v. 24, n. 4, p. 246-251, 1982 b.

PINHEIRO, F.; TRAVASSOS DA ROSA, A. P. ;; VASCONCELOS P. Arboviral Zoonoses of Central and South America. 2. ed. Boca Raton FL.: [s.n.].

PINHEIRO, F.; TRAVASSOS DA ROSA, A.; VASCONCELOS, P. F. Tratado de infectologia. In: VERONESI, R.; FOCACCIA, R. (Eds.). . Tratado de Infectologia. Sao Paulo, Brazil: [s.n.]. p. 169-180.

PINHEIRO F, P. et al. Oropouche Fever. In: FEIGIN, R. D. (Ed.). . Textbook of pediatric infections diseases. 5. ed. Philadelphia: [s.n.]. p. 2418-2423.

PINHEIRO F, P.; TRAVASSOS DA ROSA, A.; VASCONCELOS, P. F. C. Febre por Oropouche. In: LEÃO, R. N. Q. (Ed.). . Doenças Infecciosas e Parasitarias, Enfoque Amazônico. Belém : [s.n.].

PROENCA-MODENA, J. L. et al. Oropouche virus infection and pathogenesis are restricted by MAVS, IRF-3, IRF-7, and type I interferon signaling pathways in nonmyeloid cells. $\mathbf{J}$ Virol, v. 89, n. 9, p. 4720-4737, 2015.

RAMANATHAN, H. N. et al. Dynein-dependent transport of the hantaan virus nucleocapsid protein to the endoplasmic reticulum-Golgi intermediate compartment. Journal of virology, v. 81, n. 16, p. 8634-47, ago. 2007.

RAUT, C. G. et al. Susceptibility of laboratory-bred rodents to the experimental infection with dengue virus type 2. Acta virologica, v. 40, n. 3, p. 143-6, jun. 1996.

RODRIGUES, A. H. et al. Oropouche virus experimental infection in the golden hamster (Mesocrisetus auratus). Virus Res, v. 155, n. 1, p. 35-41, 2011. 
RODRIGUES, A. H. Virus Oropouche inativado: estudo de eficacia protetora contra desafio em modelo de infecção experimental em hamster. [s.1.] Universidade de São Paulo, 2012.

SAEED, M. F. et al. Diagnosis of Oropouche virus infection using a recombinant nucleocapsid protein-based enzyme immunoassay. Journal of clinical microbiology, v. 39, n. 7, p. 2445-52, jul. 2001.

SANGER, F.; NICKLEN, S.; COULSON, A. R. DNA sequencing with chain-terminating inhibitors. 1977. Biotechnology (Reading, Mass.), v. 24, p. 104-8, 1992.

SANTOS, R. I. et al. Oropouche virus entry into HeLa cells involves clathrin and requires endosomal acidification. Virus Res, v. 138, n. 1-2, p. 139-143, 2008.

SANTOS, R. I. et al. Experimental infection of suckling mice by subcutaneous inoculation with Oropouche virus. Virus Res, v. 170, n. 1-2, p. 25-33, 2012.

SANTOS, R. I. et al. Spread of Oropouche virus into the central nervous system in mouse. Viruses, v. 6, n. 10, p. 3827-3836, 2014.

SCHLESINGER, R. W. Dengue viruses. Virology monographs. Die Virusforschung in Einzeldarstellungen, n. 16, p. 1-132, 1977.

SIMMONS, M. et al. Evaluation of the protective efficacy of a recombinant dengue envelope B domain fusion protein against dengue 2 virus infection in mice. The American journal of tropical medicine and hygiene, v. 58, n. 5, p. 655-62, maio 1998.

SNIPPE, M. et al. Tomato spotted wilt virus Gc and N proteins interact in vivo. Virology, v. 357, n. 2, p. 115-23, 20 jan. 2007.

SRIVASTAVA, A. K. et al. Mice immunized with a dengue type 2 virus E and NS1 fusion protein made in Escherichia coli are protected against lethal dengue virus infection. Vaccine, v. 13, n. 13, p. 1251-1258, 1995.

TALMON, Y. et al. Electron microscopy of vitrified-hydrated La Crosse virus. Journal of virology, v. 61, n. 7, p. 2319-2321, 1987. 
TILSTON-LUNEL, N. L. et al. Genetic analysis of members of the species Oropouche virus and identification of a novel M segment sequence. J Gen Virol, v. 96, n. Pt 7, p. 1636-1650, 2015a.

TILSTON-LUNEL, N. L. et al. Generation of recombinant Oropouche orthobunyaviruses lacking the non-structural proteins NSm or NSs. J Virol, $2015 b$.

TILSTON-LUNEL, N. L. et al. Generation of Recombinant Oropouche Viruses Lacking the Nonstructural Protein NSm or NSs. Journal of virology, v. 90, n. 5, p. 2616-2627, 2015c.

VASCONCELOS, H. B. et al. Oropouche fever epidemic in Northern Brazil: epidemiology and molecular characterization of isolates. J Clin Virol, v. 44, n. 2, p. 129-133, 2009.

VASCONCELOS, H. B. et al. Molecular epidemiology of Oropouche virus, Brazil. Emerg Infect Dis, v. 17, n. 5, p. 800-806, 2011.

VASCONCELOS, P. F. et al. [1st register of an epidemic caused by Oropouche virus in the states of Maranhao and Goias, Brazil]. Rev Inst Med Trop Sao Paulo, v. 31, n. 4, p. 271$278,1989$.

WATTS, D. M. et al. Oropouche virus transmission in the Amazon River basin of Peru. Am J Trop Med Hyg, v. 56, n. 2, p. 148-152, 1997a.

WATTS, D. M. et al. Oropouche virus transmission in the Amazon River basin of Peru. The American journal of tropical medicine and hygiene, v. 56, n. 2, p. 148-52, fev. 1997b. 